\title{
Long-term time series of Arctic tropospheric BrO derived from UV-VIS satellite remote sensing and its relation to first-year sea ice
}

\author{
Ilias Bougoudis ${ }^{1}$, Anne-Marlene Blechschmidt ${ }^{1}$, Andreas Richter ${ }^{1}$, Sora Seo ${ }^{1}$, John Philip Burrows ${ }^{1}$, Nicolas Theys ${ }^{2}$, \\ and Annette Rinke ${ }^{3}$ \\ ${ }^{1}$ Institute of Environmental Physics, University of Bremen, 28359 Bremen, Germany \\ ${ }^{2}$ Belgian Institute for Space Aeronomy (BIRA-IASB), Brussels, Belgium \\ ${ }^{3}$ Alfred Wegener Institute Helmholtz Centre for Polar and Marine Research, Potsdam, Germany
}

Correspondence: Ilias Bougoudis (ibougoudis@iup.physik.uni-bremen.de)

Received: 10 February 2020 - Discussion started: 16 March 2020

Revised: 8 August 2020 - Accepted: 25 August 2020 - Published: 22 October 2020

\begin{abstract}
Every polar spring, phenomena called bromine explosions occur over sea ice. These bromine explosions comprise photochemical heterogeneous chain reactions that release bromine molecules, $\mathrm{Br}_{2}$, to the troposphere and lead to tropospheric plumes of bromine monoxide, $\mathrm{BrO}$. This autocatalytic mechanism depletes ozone, $\mathrm{O}_{3}$, in the boundary layer and troposphere and thereby changes the oxidizing capacity of the atmosphere. The phenomenon also leads to accelerated deposition of metals (e.g., $\mathrm{Hg}$ ). In this study, we present a 22-year (1996 to 2017) consolidated and consistent tropospheric $\mathrm{BrO}$ dataset north of $70^{\circ} \mathrm{N}$, derived from four different ultraviolet-visible (UV-VIS) satellite instruments (GOME, SCIAMACHY, GOME-2A and GOME-2B). The retrieval data products from the different sensors are compared during periods of overlap and show good agreement (correlations of $0.82-0.98$ between the sensors). From our merged time series of tropospheric BrO vertical column densities (VCDs), we infer changes in the bromine explosions and thus an increase in the extent and magnitude of tropospheric $\mathrm{BrO}$ plumes during the period of Arctic warming. We determined an increasing trend of about $1.5 \%$ of the tropospheric BrO VCDs per year during polar springs, while the size of the areas where enhanced tropospheric BrO VCDs can be found has increased about $896 \mathrm{~km}^{2} \mathrm{yr}^{-1}$. We infer from comparisons and correlations with sea ice age data that the reported changes in the extent and magnitude of tropospheric BrO VCDs are moderately related to the increase in first-year ice extent in the Arctic north of $70^{\circ} \mathrm{N}$, both tem-
\end{abstract}

porally and spatially, with a correlation coefficient of 0.32 . However, the $\mathrm{BrO}$ plumes and thus bromine explosions show significant variability, which also depends, apart from sea ice, on meteorological conditions.

\section{Introduction}

Arctic surface air temperature has risen at twice the rate of the global mean over the past three decades. This phenomenon is called Arctic amplification (Serreze and Barry, 2011), and our understanding of its causes is inadequate ( $\mathrm{Pi}$ than and Mauritsen, 2014; Stjern et al., 2019). Important consequences of the rapidly increasing temperature in the Arctic are the loss of ice, resulting in the reduction of ice extent; loss of thickness; and a reduced fraction of multiyear ice (Stroeve et al., 2012) and the increasing rate of loss of the Greenland ice cap (Mouginot et al., 2019). The reduced multiyear ice is being replaced by first-year ice, which is in addition more saline. (Galley et al., 2016). Both the maximum and the minimum yearly sea ice extent began to be noticeably smaller over a decade ago. The minimum sea ice extent, which occurs usually in September, reached its record low in 2012 (Yang and Magnusdottir, 2018). The yearly maximum sea ice extent, which occurs every March, is shrinking at a significant rate (Serreze and Meier, 2019). The thickness of sea ice has declined dramatically in recent years as the portion of thick multiyear ice decreases (Richter-Menge et al., 2017). Sea ice 
is replaced by open ocean, which being darker reduces surface reflectivity in the Arctic. As a result, more of the incoming solar radiation is absorbed by the ocean and its biosphere (e.g., phytoplankton). Consequently, the temperature of the ocean and the air in the boundary layer increases, creating a positive feedback loop. This is one of the most pronounced effects occurring during Arctic amplification (Hansen et al., 1997; Kirtman et al., 2013). These evolving conditions impact many other physical, chemical and biological processes, as well as the ecosystem in the Arctic.

Bromine monoxide $(\mathrm{BrO})$ plays a significant role in the atmospheric chemistry of the Arctic. During polar springtime, episodes of strongly enhanced amounts of $\mathrm{BrO}$ have been observed in the boundary layer (Barrie and Platt, 1997). The formation of these intense plumes of $\mathrm{BrO}$ results in tropospheric ozone depletion. Tropospheric ozone depletion and the link to halogen chemistry events was first discovered over 30 years ago (Barrie et al., 1988) and has been the subject of many studies and research campaigns over the past three decades (Toohey et al., 1990; Tuckermann et al., 1997; SaizLopez and Glasow, 2012). The release of reactive halogens and the decrease in ozone $\left(\mathrm{O}_{3}\right)$ impacts the oxidizing capacity of the troposphere. The photolysis of $\mathrm{O}_{3}$ in the UVB leads to the formation of the most important tropospheric oxidizing agent, the hydroxyl radical, $\mathrm{OH}$ (Lelieveld et al., 2016). Although bromine radicals can contribute to the formation of $\mathrm{OH}$ on short timescales, the destruction of ozone caused by reactive bromine lowers the $\mathrm{OH}$ concentrations and is more profound (Stone et al., 2018). While in plumes of tropospheric $\mathrm{BrO}$ the oxidizing agents $\mathrm{O}_{3}$ and $\mathrm{OH}$ are reduced, the reactions of $\mathrm{BrO}$ play also other important roles in atmospheric chemistry. For example, BrO efficiently reacts with elemental mercury. This oxidation initiates a process whereby deposition of mercury, $\mathrm{Hg}$, to snow and ice increases. This results in $\mathrm{Hg}$ entering the food chain ( $\mathrm{Lu}$ et al., 2001; Schroeder et al., 1998). The rapid and sudden appearance of $\mathrm{BrO}$ plumes over the polar regions has been called the "bromine explosion" (Barrie and Platt, 1997; Platt and Lehrer, 1997). It is explained by an autocatalytic multiphase chemical cycle, which occurs on cold saline surfaces (Fan and Jacob, 1992; Sander and Crutzen, 1996). Although there are studies which try to model $\mathrm{BrO}$ plumes from their driving mechanisms (Falk and Sinnhuber, 2018; Seo et al., 2019b; Huang et al., 2020), the exact level of impact of each parameter on the formation of enhanced tropospheric $\mathrm{BrO}$ is uncertain. However, there is the general consensus that the potential sources of $\mathrm{BrO}$ plumes are (a) rich in sea salts and relatively cold (conditions occurring in potential frost flowers regions; Rankin et al., 2002; Kaleschke et al., 2004; Sander et al., 2006), (b) surfaces covered with liquid or frozen brine (Sander et al., 2006), (c) associated with blowing snow (Yang et al., 2008; Blechschmidt et al., 2016; Frey et al., 2020), and (d) surface snow packs (Pratt et al., 2013; Peterson et al., 2018) and young salty sea ice regions (Wagner et al., 2001; Simpson et al., 2007; Peterson et al., 2016). A pH lower than
6.5 is required for efficient bromine activation (Fickert et al., 1999; Halfacre et al., 2019).

Organic sources of $\mathrm{BrO}$, such as oceanic organobromine compounds, have also been discussed in the literature (Salawitch et al., 2006, and references therein), but their relatively long lifetimes result in a slow release of $\mathrm{Br}$ throughout the Arctic troposphere or beyond and are currently not considered to explain a significant part of the bromine explosion mechanism. Starting with molecular bromine in the gas phase, the sequence of autocatalytic chain reactions describing the bromine explosion reactions can be written in its simplest form as

$$
\begin{aligned}
& \mathrm{Br}_{2}+\mathrm{hr}(350 \mathrm{~nm}<\lambda<500 \mathrm{~nm}) \rightarrow 2 \mathrm{Br}, \\
& 2\left(\mathrm{Br}+\mathrm{O}_{3} \rightarrow \mathrm{BrO}+\mathrm{O}_{2}\right), \\
& 2\left(\mathrm{BrO}+\mathrm{HO}_{2} \rightarrow \mathrm{HOBr}+\mathrm{O}_{2}\right), \\
& 2\left(\mathrm{HOBr}_{(\mathrm{g})} \rightleftharpoons \mathrm{HOBr}(\mathrm{aq}),\right. \\
& 2\left(\mathrm{HOBr}_{(\mathrm{aq})}+\mathrm{Br}_{(\mathrm{aq})}^{-}+\mathrm{H}_{(\mathrm{aq})}^{+} \rightarrow \mathrm{Br}_{2(\mathrm{~g})}+\mathrm{H}_{2} \mathrm{O}_{(\mathrm{aq})}\right) \\
& \mathrm{Net}_{2} \mathrm{O}_{3}+2 \mathrm{HO}_{2}+2 \mathrm{Br}_{(\mathrm{aq})}^{-}+2 \mathrm{H}_{(\mathrm{aq})}^{+} \rightarrow 4 \mathrm{O}_{2}+2 \mathrm{H}_{2} \mathrm{O}+\mathrm{Br}_{2} .
\end{aligned}
$$

In short, the autocatalytic multiphase chain reaction releases molecular bromine, $\mathrm{Br}_{2}$, to be photolyzed by solar radiation (hv) (Reaction R1). The resulting bromine atoms rapidly remove tropospheric $\mathrm{O}_{3}$ (Reaction $\mathrm{R} 2$ ). The resultant $\mathrm{BrO}$ reacts with $\mathrm{HO}_{2}$ to form $\mathrm{HOBr}$ (Reaction R3). This enters the aqueous phase or quasi-liquid layers on cold brine or snow and ice (Reaction R4), where it reacts with halogen ions to release $\mathrm{Br}_{2}$ to the atmosphere (Reaction R5). The efficiency of such a chain reaction depends on the chain length in the atmosphere. The ratio of the relative rate of chain propagation to chain termination reactions of the chain carriers, i.e., the $\mathrm{Br}$ and $\mathrm{BrO}$, determines the chain length. The bromine explosion slows through the depletion of $\mathrm{O}_{3}$ in the air mass, or through reactions of $\mathrm{Br}$ or $\mathrm{BrO}$ with formaldehyde or $\mathrm{NO}_{2}$ :

$$
\begin{aligned}
& \mathrm{Br}+\mathrm{HCHO} \rightarrow \mathrm{HBr}+\mathrm{HCO}, \\
& \mathrm{BrO}+\mathrm{NO}_{2}+\mathrm{M} \rightarrow \mathrm{BrONO}_{2}+\mathrm{M}, \\
& \mathrm{BrONO}_{2(\mathrm{~g})} \rightleftharpoons \mathrm{BrONO}_{2(\mathrm{aq})} .
\end{aligned}
$$

In addition, there are cycles involving chlorine ions also initiating the release of $\mathrm{BrCl}$, which leads to further catalytic loss of $\mathrm{O}_{3}$. The involved reactions are explained in more detail elsewhere (e.g., Simpson et al., 2007; Sander et al., 2006).

It was shown that $\mathrm{BrO}$ plumes can be transported far from their initial formation areas, as high wind speeds associated with cyclones (Begoin et al., 2010; Zhao et al., 2016; Blechschmidt et al., 2016) can transfer them together with blowing snow (Giordano et al., 2018). Peterson et al. (2017) studied the vertical transport of $\mathrm{BrO}$ and its recycling on aerosol particles, stating that $\mathrm{BrO}$ can be sustained, reformed and transferred on aerosols. Using a qualitative model, Jones et al. (2009) have shown that both a stable boundary layer with very low near surface wind speed conditions and an un- 
stable boundary layer with high-wind-speed conditions increase the number of reactants in the air and hence favor the bromine explosion. There are also several studies which tried to model tropospheric BrO plumes. Yang et al. (2020) used both a chemistry transport and a chemistry climate model to model tropospheric $\mathrm{BrO}$ and compared the outputs with satellite columns and ground-based measurements. Fernandez et al. (2019) provided 4 years of polar spring comparisons between GOME-2A instrument columns and model runs, for the Arctic and Antarctic, having implemented polar halogen chemistry into the CAM-Chem model.

The polar regions are some of the most remote places on the planet. Consequently, satellite remote sensing is a suitable method to study bromine chemistry in the Arctic. Richter et al. (1998) and Wagner and Platt (1998) were the first studies on satellite observations of $\mathrm{BrO}$ plumes in polar regions, using the GOME instrument (Richter et al., 1998; Wagner and Platt, 1998; Burrows et al., 1999). Based on observations from the same instrument, Hollwedel et al. (2004) derived a 6-year time series of Arctic and Antarctic total vertical column densities (VCDs) of BrO. This was the first scientific effort to study the evolution of $\mathrm{BrO}$ in the polar regions. The transport of $\mathrm{BrO}$ plumes, which represents a photostationary state with production and loss processes and their capability of depleting ozone, far away from the initial release area was studied with satellite remote sensing (Ridley et al., 2007; Begoin et al., 2010). The relationship between $\mathrm{BrO}$ release and young sea ice was also discussed (Wagner et al., 2001), where it was indicated that $\mathrm{BrO}$ concentrations are always found over or near sea ice on the Caspian Sea. Van Roozendael et al. (2004) used SCIAMACHY observations for Arctic $\mathrm{BrO}$ and compared them to GOME data, showing satisfactory agreement between the two different sensors. Theys et al. (2011) compared tropospheric $\mathrm{BrO}$ columns derived from GOME-2A to a chemical transport model, showing consistency with the release mechanisms of bromine. Sihler et al. (2012) compared GOME-2 BrO columns to ground-based measurements in the Arctic, demonstrating good agreement between them. Seo et al. (2019a) presented the first BrO retrievals from the TROPOspheric Monitoring Instrument (TROPOMI), showing high-resolution $\mathrm{BrO}$ cases with low fitting errors. Studies have also used satellite remote sensing to link bromine explosion events to their sources and triggering meteorological conditions to better understand this complex and significant phenomenon. For instance, Choi et al. (2018), Begoin et al. (2010), Toyota et al. (2011) and Jones et al. (2009) investigated links between tropospheric $\mathrm{BrO}$ and blowing snow. Blechschmidt et al. (2016) investigated a bromine explosion event using GOME-2A and associated its long lifetime with the continuous release of bromine molecules from blowing snow along the front of a polar cyclone.

Changes in meteorological parameters - e.g., increasing air temperature (Serreze and Barry, 2011), decreasing mean sea level pressure over northeastern America and increas- ing pressure over Eurasia (Ogawa et al., 2018; McCusker et al., 2016), the increase in cyclone frequency and intensity (Akperov et al., 2019), stronger surface winds (Mioduszewski et al., 2018) and changes in sea ice conditions (e.g., reduced sea ice extent; Stroeve et al., 2012), increased first-year sea ice fraction (and consequently salinity), and therefore decreased sea ice thickness (Richter-Menge et al., 2017) - occur due to Arctic warming. It is therefore likely that the intensity, frequency and spatial distribution of bromine explosions in the Arctic are changing. These changes can potentially impact the $\mathrm{O}_{3}$ abundances and the oxidant $\mathrm{OH}$ at high latitudes. Consequently, the objectives of this study are (a) to derive the first consolidated and consistent long-term Arctic tropospheric $\mathrm{BrO}$ dataset using satellite remote sensing and (b) to investigate and understand changes or trends in $\mathrm{BrO}$ and the relation to changes in sea ice, based on the new dataset. As described above, an earlier effort was carried out by Hollwedel et al. (2004), but they did not extract the tropospheric BrO column from their 6-year GOME dataset. Choi et al. (2018) used an 11-year Arctic tropospheric $\mathrm{BrO}$ dataset from the Ozone Monitoring Instrument (OMI) and investigated the link to first-year sea ice and sea salt aerosols released from blowing snow. However, the OMI sensor suffers from instrumental degradation, known as row anomaly (Class et al., 2010). In our study, we use measurements from four ultraviolet-visible satellite instruments to derive tropospheric VCDs of BrO over the Arctic, covering a time span of 22 years, starting with GOME observations in 1996 and ending with GOME-2A and GOME-2B in 2017. We first retrieve $\mathrm{BrO}$ slant column densities (SCDs) for each instrument and then separate tropospheric VCDs from stratospheric BrO amounts.

The remainder of this paper is structured as follows: in Sect. 2, a short technical description of the instruments used in this study is presented. In Sect. 3, the methods applied for retrieving geometric and tropospheric $\mathrm{BrO}$ columns from the satellite sensors and the additional datasets used for stratospheric separation and sea ice flagging of tropospheric $\mathrm{BrO}$ are introduced. In Sect. 4, an analysis of the long-term data is presented, including time series and maps of tropospheric BrO VCDs and comparisons with sea ice age and a statistical analysis of possible trends of tropospheric BrO VCDs. The paper ends with a summary and conclusions (Sect. 5).

\section{Instruments}

The technical attributes of the satellite sensors that are used, together with information about instrumental degradation, are described in the following. A short summary of characteristics of the sensors is given in Table 1. 
Table 1. Attributes of the satellite instruments used in this study.

\begin{tabular}{llllll}
\hline Instrument & Platform & Period & Footprint & $\begin{array}{l}\text { Equatorial } \\
\text { overpass }\end{array}$ & Swath \\
\hline GOME & ERS-2 & $1996-2003$ & $320 \mathrm{~km} \times 40 \mathrm{~km}$ & $10: 30 \mathrm{LT}$ & $960 \mathrm{~km}$ \\
\hline SCIAMACHY & Envisat & $2002-2012$ & $30 \mathrm{~km} \times 60 \mathrm{~km}$ & $10: 00 \mathrm{LT}$ & $960 \mathrm{~km}$ \\
\hline GOME-2A & Metop-A & 2007-present & $\begin{array}{l}80 \mathrm{~km} \times 40 \mathrm{~km} \\
40 \mathrm{~km} \times 40 \mathrm{~km} \\
(\text { since June 2013) }\end{array}$ & $09: 30 \mathrm{LT}$ & $\begin{array}{l}1920 \mathrm{~km} \\
960 \mathrm{~km} \\
\end{array}$ \\
& & & since June 2013) \\
\hline GOME-2B & Metop-B & 2012-present & $80 \mathrm{~km} \times 40 \mathrm{~km}$ & $09: 30 \mathrm{LT}$ & $1920 \mathrm{~km}$ \\
\hline
\end{tabular}

\subsection{GOME}

The GOME (Global Ozone Monitoring Experiment) (Burrows et al., 1999) instrument was launched in 1995 on ERS2. It was a nadir viewing scanning spectrometer, observing solar backscattered radiation upwelling from the Earth's surface and atmosphere. It measured continuously in four spectral channels from 240 to $790 \mathrm{~nm}$, with a spectral resolution between 0.2 and $0.4 \mathrm{~nm}$. For $27 \mathrm{~d}$ per month, the spatial resolution of the forward scans was $40 \mathrm{~km} \times 320 \mathrm{~km}$, and the swath was $960 \mathrm{~km}$. For approximately $3 \mathrm{~d}$ per month, the instrument operated in narrow-swath mode with a swath width of $240 \mathrm{~km}$ and ground scenes having a spatial resolution of $40 \mathrm{~km} \times 80 \mathrm{~km}$. ERS-2 was in a Sun-synchronous orbit with a 10:30 local time Equator overpass in the descending node. GOME was the first satellite instrument, which was able to measure key tropospheric gases which have weaker absorption lines than ozone: examples are $\mathrm{NO}_{2}, \mathrm{BrO}, \mathrm{HCHO}$ and $\mathrm{SO}_{2}$ (Burrows et al., 1999). The instrument was launched in July 1995 and lost its global coverage in 2003 due to data rate limitation (the onboard storage capability of the instrument was disabled and as a result data could only be transmitted directly to ground stations) (Bracher et al., 2005).

\subsection{SCIAMACHY}

SCIAMACHY (SCanning Imaging Absorption spectroMeter for Atmospheric CHartographY) (Bovensmann et al., 1999; Burrows et al., 1995) was a satellite spectrometer on board Envisat. It was launched into space in 2002. The main advantage of SCIAMACHY compared to GOME was its broader spectral coverage, ranging from 210 to $2380 \mathrm{~nm}$, allowing the observation of many trace gases in the near infrared $(0.75$ to $1.4 \mu \mathrm{m})$ and shortwave infrared $(1.4$ to $3 \mu \mathrm{m})$ spectral regions. SCIAMACHY's spectral resolution was 0.2 to $0.5 \mathrm{~nm}$, and its spatial resolution in the spectral region used for $\mathrm{BrO}$ retrievals was $30 \mathrm{~km} \times 60 \mathrm{~km}$, with a $960 \mathrm{~km}$ swath width in nadir. The overpass of Envisat over the Equator was at 10:00 local time. SCIAMACHY observed the Earth in nadir, limb and occultation geometries, providing a wealth of trace gas data on the atmosphere from the surface to the upper atmo- sphere (Bovensmann et al., 1999). In April 2012, Envisat lost contact with the ground station, and as a result, the mission was terminated.

\subsection{GOME-2}

The series of GOME-2 (Global Ozone Monitoring Experiment-2) (Callies et al., 2000) instruments were developed as the successors of GOME. There are currently three instruments in orbit, one launched on board Metop-A in 2006, one on Metop-B in 2012 and one on Metop-C in 2018. Here, we use data from GOME-2A and GOME-2B. All GOME-2 instruments share the same attributes and sense the Earth's backscattered radiance and extraterrestrial solar irradiance in the ultraviolet and visible part of the spectrum $(240$ to $790 \mathrm{~nm})$. They have a spectral resolution between 0.2 and $0.4 \mathrm{~nm}$, while the footprint size is $80 \mathrm{~km} \times 40 \mathrm{~km}$ and has a much wider swath $(1920 \mathrm{~km})$ than the previous instruments. GOME-2A changed its swath to $960 \mathrm{~km}$ and footprint to $40 \mathrm{~km} \times 40 \mathrm{~km}$ in June 2013. The GOME-2 instruments cross the Equator at 09:30 local time (Callies et al., 2000). All three instruments are currently in operation.

\subsection{Instrumental degradation}

Spaceborne optical instruments often suffer from a decrease in throughput in the ultraviolet spectral region, which arises from the deposition of absorbing layers on the optical surfaces such as mirrors, lenses or gratings. This results in a variety of effects such as loss of throughput and changing etalons in the instrument. The quality of the retrieved $\mathrm{BrO}$ data, which are produced from the weak absorption signal in the UV region, is influenced by these degradations. The GOME, SCIAMACHY and GOME-2 teams identify any degradation in the reflectances and correct where appropriate and possible. For example, organic compounds and water, emitted by the spacecraft, are photochemically transformed by UV-B and vacuum UV from the Sun and most likely form long-chain polymers, which have low vapor pressure and are adsorbed on the mirrors. In this context, Snel (2000) showed that the GOME sensor experienced degradation in all wavelength regions but in particular in the UV, consistent with 
degradation of the scan mirror. Krijger et al. (2007) compared the degradation of GOME to SCIAMACHY with respect to the reflectivity. Dikty et al. (2011) investigated the impact of GOME-2A throughput loss on various time series of trace gases. Most of the major degradation effects on the sensors are identified and documented in the literature and where possible accounted for (Munro et al., 2016; Garcia et al., 2016). In addition, GOME-2A recently moved into a drift in orbit, and there are periods during which solar measurements are no longer feasible.

\section{Methods}

In this section, the methodology used to retrieve BrO SCDs from the satellite measurements and to obtain tropospheric BrO VCDs and datasets used in this study are described.

\subsection{Retrieval of BrO slant column densities}

Similar to previous studies on atmospheric BrO from hyperspectral satellite remote sensing observations in the solar spectral regions, the retrieval algorithm uses the differential optical absorption spectroscopy (DOAS) method (Platt and Perner, 1983; Burrows et al., 2011). DOAS evolves from the Beer and Lambert law, which describes the attenuation of electromagnetic radiation in a medium:

$I=I_{\mathrm{o}} e^{-\int \sum_{j=1}^{J}\left\{\sigma_{j}(\lambda) \rho_{j}\right\} \mathrm{d} s}$,

where $I$ is the measured intensity of the electromagnetic radiation, $I_{\mathrm{O}}$ is the initial intensity, $J$ is the total number of trace gases absorbing, $j$ denotes a particular trace gas (e.g., $\mathrm{BrO}), \sigma(\lambda)$ is the cross section of the absorber at wavelength $\lambda$ and $\rho$ is the concentration of the trace gas. The integral is taken along the light path $s$.

The atmospheric absorption of trace gases of interest can be retrieved by using knowledge of their characteristic spectral fingerprints. This is achieved by separating the extinction signal into a low-frequency and a high-frequency part. The low-frequency part is treated as a closure term and is fitted by a low-order polynomial. The higher-frequency term contains the absorption structures of the trace gases. The final output of the retrieval is the slant column density of the trace gas, i.e., the density of the trace gas, integrated along the light path (Platt and Stutz, 2008):

$\operatorname{SCD}_{j}=\int \rho_{j}(s) \mathrm{d} s$,

The radiance upwelling at the top of the atmosphere is approximated at a given wavelength by

$I(\lambda)=\alpha(\lambda) I_{\mathrm{o}}(\lambda)$

$e^{-\int \sum_{j=1}^{J}\left\{\sigma_{j}(\lambda) \mathrm{SCD}_{j}+\sigma_{\mathrm{Ray}}(\lambda) \mathrm{SCD}(\mathrm{Ray})+\sigma_{\mathrm{Mie}}(\lambda) \mathrm{SCD}(\mathrm{Mie})\right\} \mathrm{d} s}$, where $\alpha$ is the scattering efficiency, $\operatorname{SCD}_{j}$ is the slant column density of the gas with index $j, \sigma_{\text {Ray }}(\lambda)$ and $\sigma_{\text {Mie }}(\lambda)$ are the scattering cross sections of Rayleigh scattering molecules (e.g., primarily air molecules, molecular nitrogen $\mathrm{N}_{2}$ and oxygen, $\mathrm{O}_{2}$ ) and Mie scattering particles (e.g., aerosol particles), and SCD(Ray) and SCD(Mie) are the corresponding slant columns of Rayleigh and Mie scatterers. As Rayleigh and Mie scattering efficiency varies smoothly with wavelength, they can be approximated by low-order polynomials. This results in the following approximation:

$\ln \frac{I_{\mathrm{o}}(\lambda)}{I(\lambda)}=\sum_{j} \sigma_{j}(\lambda) \operatorname{SCD}_{j}-\sum_{\mathrm{p}} b_{\mathrm{p}} \lambda^{\mathrm{p}}$,

where $b_{\mathrm{p}}$ represents the coefficients of the polynomial. Variants on Eq. (4) are also employed to fit the spectra. To retrieve accurate BrO SCDs, an optimal selection of the spectral window, which maximizes the information content with respect to the $\mathrm{BrO}$ absorption, and the selection of corresponding cross sections of other trace gases absorbing in the same spectral window are the first step. We chose to use temperature-dependent cross sections of ozone (dominant absorber in the UV) following Serdyuchenko et al. (2014) at 223 and 243 Kelvin and a BrO cross section (Fleischmann et al., 2004) at 223 Kelvin. In addition, a pseudo-cross section is used for simulating the filling in of Fraunhofer lines by Raman scattering known as the Ring effect (Vountas et al., 1998), and another pseudo-cross section, which deals with the issue of poor spectral sampling (Chance et al., 2005), was included in the fitting for all instruments. The high-spectralresolution absorption cross sections were convolved by the slit function of each instrument. The impact of using different combinations of trace gas absorptions on the fit of BrO SCD was investigated. It was found that the omission of the explicit fitting of $\mathrm{NO}_{2}$ and $\mathrm{SO}_{2}$ has a minimal impact on the fit of the BrO SCD north of $70^{\circ} \mathrm{N}$. The differences in BrO SCD between fits with and without $\mathrm{NO}_{2}$ or $\mathrm{SO}_{2}$ in the selected spectral ranges were typically less than $1 \%$ of the BrO SCD. Consequently, we decided to use only the cross sections of the dominant absorber $\mathrm{O}_{3}$ in this region and of the trace gas of interest itself, $\mathrm{BrO}$, in the nonlinear least squares SCD fitting. The differences between fits of BrO SCD using fourthand fifth-order polynomials were small and the quality of the fit improved significantly from a third- to fourth-degree polynomial fit. These results led to the selection of the use of the fourth-order polynomial in our retrieval. The selection of parameters used in this study is appropriate for BrO columns in the region north of $70^{\circ} \mathrm{N}$.

As $\mathrm{BrO}$ is a relatively weak absorber, small changes in the input parameters and especially of the fitting window of the retrieval lead to large changes in the quality of the fit. Although there are many good practices developed for the DOAS fitting window selection for an absorber (e.g., it must include at least two absorption peaks from the trace gas of interest, no large Fraunhofer lines, small interference from 
other species, etc.), there is no precise and agreed methodology to determine the optimal selection. Consequently, different spectral fitting windows for $\mathrm{BrO}$ retrievals have been used in previous studies. For example, Richter et al. (1998) used a 345-359 nm wavelength region for GOME, Afe et al. (2004) used a $336-347 \mathrm{~nm}$ fitting window for SCIAMACHY and Theys et al. (2009) used a 336 to $359 \mathrm{~nm}$ fitting window for GOME-2A. Each of the sensors has slightly different instrumental characteristics, and each of them shows different degradation behavior. Consequently, we chose the optimal spectral fitting window for each of the sensors using the following set of selection criteria: (a) smallest root mean square error (RMSE) of the fit; (b) minimal trend of BrO SCDs over a clear Pacific reference region, where no strong trend in $\mathrm{BrO}$ is expected; and (c) good agreement between retrievals from the different sensors for periods of overlapping measurements. The RMSE of the fit in absolute units is defined as where $N$ is the number of spectral points and $P(\lambda)$ the low-order polynomial. The RMSE was averaged over all the scenes in the region of interest (i.e., the Arctic from 70.0 to $85.0^{\circ} \mathrm{N}$ latitude and $180^{\circ} \mathrm{W}$ to $180^{\circ} \mathrm{E}$ longitude) and for the Pacific reference region $\left(50.0^{\circ} \mathrm{S}\right.$ to $10.0^{\circ} \mathrm{N}$ latitude and 90.0 to $125.0^{\circ} \mathrm{W}$ longitude).

Figure 1 shows the SCDs of $\mathrm{BrO}$ over the Pacific reference region and the RMSE of the fit for the Arctic and Pacific regions.

The annual cycle in the fitting RMSE for the Arctic results from changes in the Sun's position and its impact on the upwelling radiance. In spring and autumn, when the solar zenith angle is larger, the scattering and attenuation increases, and as a result, the radiance signal is low. In the Arctic, SCIAMACHY has the lowest fitting RMSE of all instruments. GOME-2A shows a rapid increase in RMSE up to 2009 and a smaller upward trend in the following years. A similar systematic increase in RMSE occurs for GOME-2B. The RMSE for the Pacific region shows a similar behavior for GOME-2A and GOME-2B, as both increase strongly with time. GOME appears to have lower RMSE values on average than the GOME-2A and GOME-2B instruments, presumably because of the lower spatial resolution, but the RMSE shows large variability. Generally, daily mean RMSE values are below $2.0 \times 10^{-3}$, for all instruments. There is no clear trend in the SCD of BrO over the Pacific region for any of the instruments.

The use of a reference area over the Pacific as background spectrum is an alternative to the use of solar irradiance measurements, which removes systematic errors arising from interfering instrumental structures in the solar irradiance measurements. The region of the Pacific is selected because of its relatively small annual cycle of $\mathrm{BrO}$ (Richter et al., 2002). In this way, the quality of the fit improves greatly as problems in the radiances mainly cancel out. Consequently, the Pacific background spectrum has been used instead of the Sun background spectrum for all instruments in the present study. Although trends over the clean Pacific background region resulting from instrumental degradation were minimized, residual trends had to be accounted for. This has been achieved by applying an additional Pacific correction to each instrument separately. The normalization method computes the average $\mathrm{BrO}$ SCD in a small Pacific area $\left(0.0^{\circ} \pm 10.0^{\circ}\right.$ latitude, $180.0^{\circ} \pm 20.0^{\circ}$ longitude) and then subtracts this average from every pixel of the BrO SCD. To compensate for the negative bias imposed by the method, a constant offset of $7 \times 10^{13}$ molec $\mathrm{cm}^{-2}$ was added for every day (Richter et al, 2002; Sihler et al., 2012). This correction tackles offset errors that occur for weak absorbers and are due to instrumental degradation (Alvarado et al., 2014).

The empirically determined sets of parameters used in the $\mathrm{BrO}$ retrievals are reported in Tables 2 and 3.

\subsection{Tropospheric BrO vertical column densities and datasets}

$\mathrm{NO}_{2}$ and $\mathrm{O}_{3}$ columns from satellite retrievals and tropopause height from meteorological reanalysis data are used for extracting the tropospheric $\mathrm{BrO}$ component from the retrieval (stratospheric separation). Sea ice data (age and type) obtained by satellite remote sensing were used in order to identify regions with sea ice cover and hence high surface reflectivity, which is required for the retrieval of tropospheric $\mathrm{BrO}$ in this study and for data interpretation in relation to bromine sources.

\subsubsection{Stratospheric separation}

In order to derive the tropospheric $\mathrm{BrO} \mathrm{VCD}$ from the retrieved SCD of BrO, the method of Theys et al. (2009) was used. Briefly, this method uses a stratospheric $\mathrm{BrO}$ climatology, derived with the BASCOE model (Errera and Fonteyn, 2001), and requires year, latitude, tropopause height, $\mathrm{O}_{3}$ and $\mathrm{NO}_{2}$ columns as input. This approach has been applied successfully in previous studies (e.g., Begoin et al., 2010; Theys et al., 2011; Blechschmidt et al., 2016; Choi et al., 2018). In the present study, satellite-retrieved $\mathrm{O}_{3}$ VCDs from Weber et al. (2013), stratospheric $\mathrm{NO}_{2}$ VCDs from the QA4ECV project (Boersma et al., 2017a, b, c) and from the Tropospheric Emission Monitoring Internet Service (TEMIS) (Boersma et al., 2004), and tropopause heights retrieved from NCEP reanalysis data (Kalnay et al., 1996) were used as input. In Theys et al. (2009), a correction factor was applied to account for the long-term reduction of bromine emissions in the stratosphere. This factor was based on ground-based zenith-sky measurements of $\mathrm{BrO}$ over Harestua (Hendrick et al., 2008). In the present study, this factor was excluded, as the long-term development of stratospheric BrO VCDs of the model without applying the correction factor comes to a closer qualitative agreement with updated measurements of $\mathrm{BrO}$ over Harestua (from F. Hendrick, BIRA-IASB, personal communication, 2019). The time series of $\mathrm{NO}_{2}, \mathrm{O}_{3}$ and tropopause height are shown in Fig. 2. 

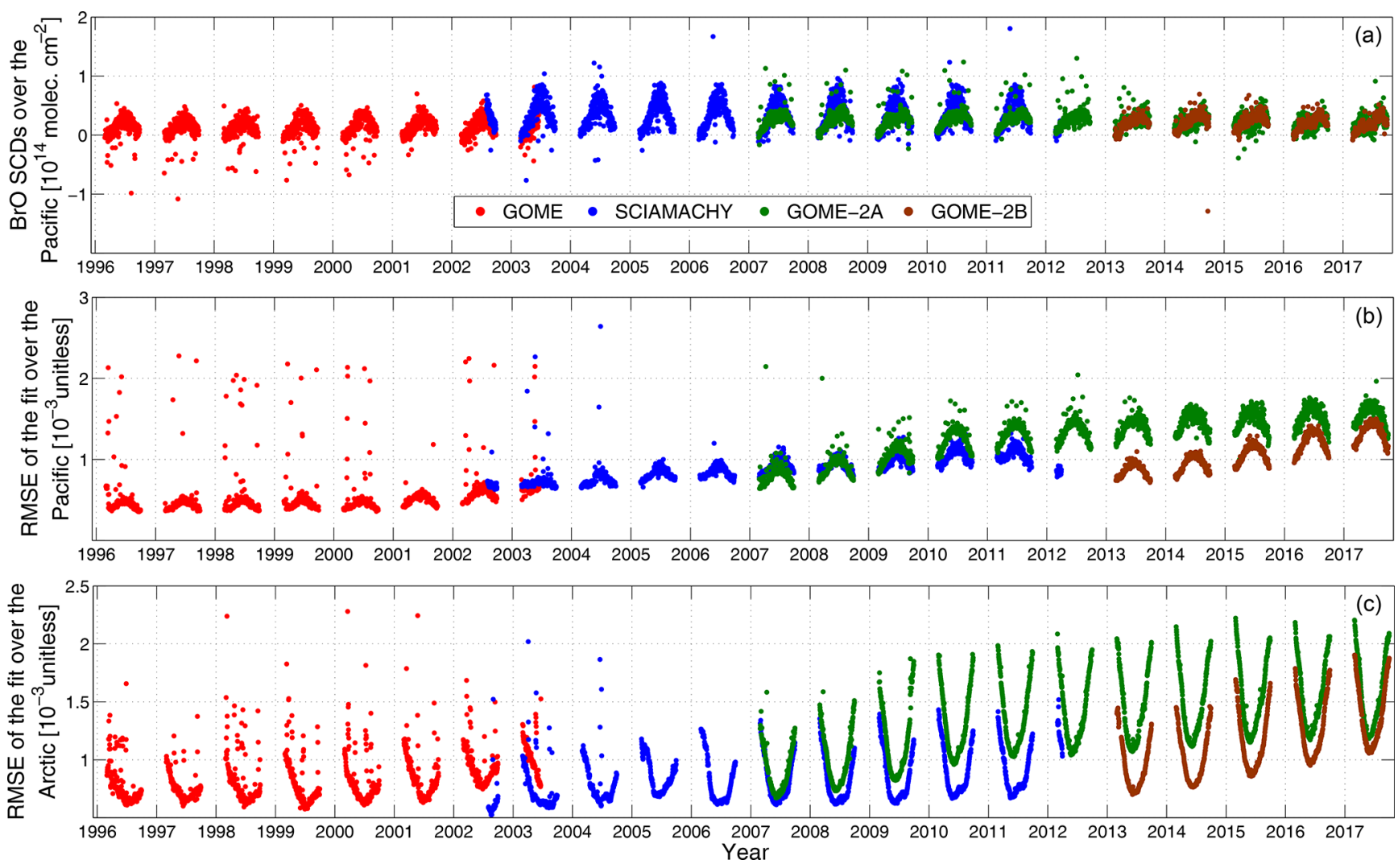

Figure 1. Time series of (a) SCDs of BrO $\left(\operatorname{molec} \mathrm{cm}^{-2}\right)$ over the Pacific, (b) fitting RMSE over the Pacific and (c) fitting RMSE over the Arctic. GOME data are shown in red, SCIAMACHY in blue, GOME-2A in green and GOME-2B in brown color.

Table 2. Parameter selection for all instruments.

\begin{tabular}{ll}
\hline Parameters & Cross sections - application selection \\
\hline Ozone, $\mathrm{O}_{3}$ & (Serdyuchenko et al., 2014), 223 and 243 K \\
$\mathrm{BrO}$ & (Fleischmann et al., 2004), 228 K \\
Ring effect & Ring cross section calculated by SCIATRAN model \\
Undersampling correction & Yes \\
Fraunhofer lines & Chance and Kurucz (Chance et al., 2010) \\
Background spectrum & Pacific area $\left(50.0^{\circ} \mathrm{S}\right.$ to $50.0^{\circ} \mathrm{N}$ lat., 125.0 $\mathrm{W}$ to 200.0 $0^{\circ} \mathrm{W}$ long.) \\
Degree of the polynomial & Fourth \\
\hline
\end{tabular}

The following formula (Theys et al., 2009) is used to derive the tropospheric $\mathrm{VCD}$ of $\mathrm{BrO}$ :

$\mathrm{VCD}_{\text {tropo }}=\left(\mathrm{SCD}_{\text {total }}-\mathrm{VCD}_{\text {strato }} \times \mathrm{AMF}_{\text {strato }}\right) / \mathrm{AMF}_{\text {tropo }}$,

where $\mathrm{SCD}_{\text {total }}$ is the slant column of $\mathrm{BrO}$ retrieved by the DOAS method, $\mathrm{VCD}_{\text {strato }}$ corresponds to the stratospheric BrO VCD retrieved from the Theys et al. (2009) climatology, $\mathrm{AMF}_{\text {strato }}$ is a stratospheric air mass factor and $\mathrm{AMF}_{\text {tropo }}$ is a tropospheric air mass factor. For the latter, as in Begoin et al. (2010) and Blechschmidt et al. (2016), a surface albedo of 0.9 has been assumed above sea ice and that all tropospheric $\mathrm{BrO}$ is well mixed within the boundary layer extending to $400 \mathrm{~m}$ altitude. Note that the stratospheric BrO VCD column is independent of the BrO SCD and only depends on the Theys et al. (2009) climatology and its inputs.

\subsubsection{Sea ice}

In order to study the connection between tropospheric $\mathrm{BrO}$ and sea ice under the impact of Arctic warming, long-term sea ice data (starting from 1996) are required in this study. In addition, since the tropospheric AMF applied for the retrieval of tropospheric $\mathrm{BrO}$ (see previous section) assumes a surface albedo of 0.9 , the sea ice data were used to remove data with no sea ice cover from the $\mathrm{BrO}$ data. For this purpose, the sea ice age dataset from Tschudi et al. (2019) was used. It is retrieved from different passive microwave satellite remote 

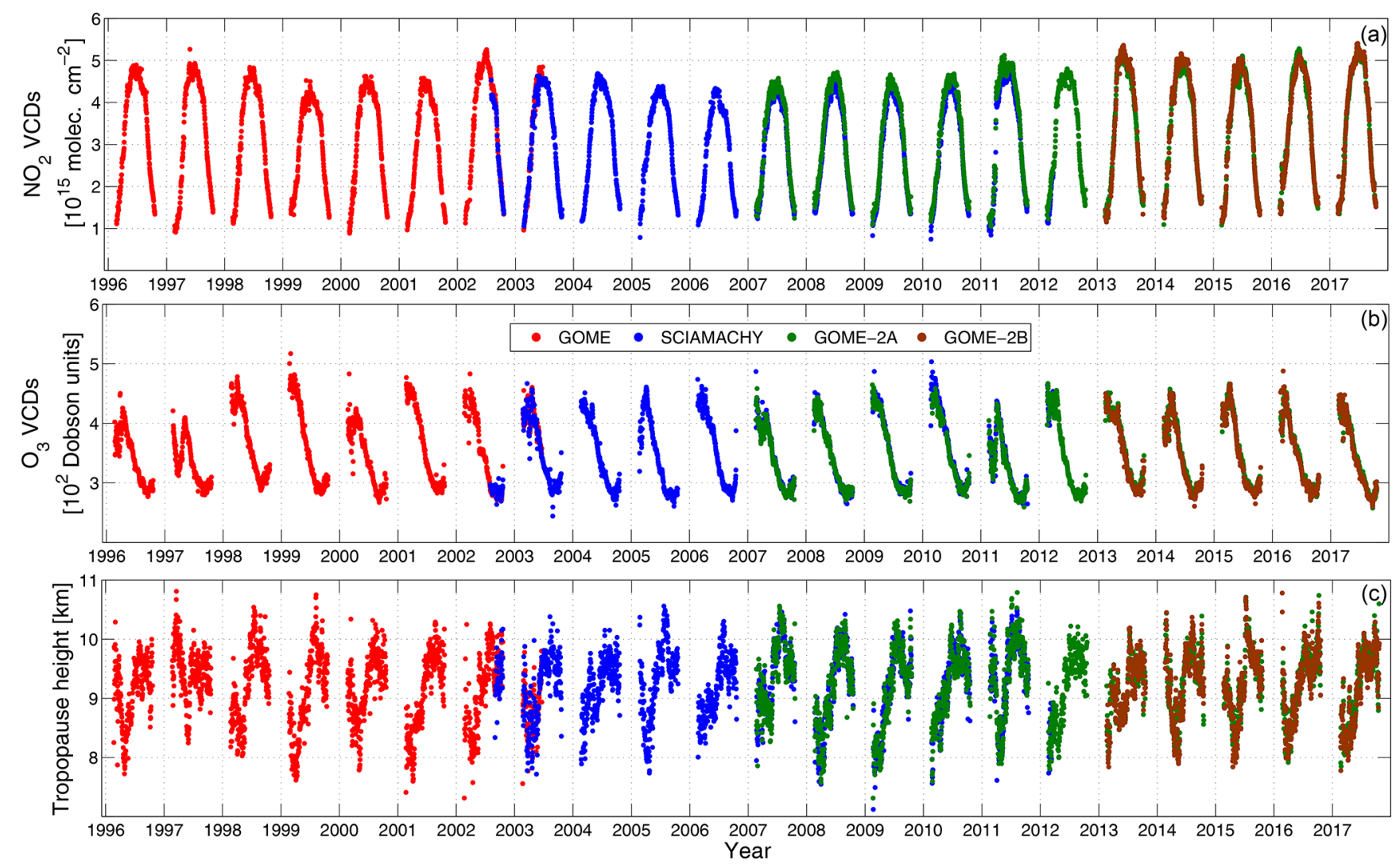

Figure 2. Time series of daily averaged input data over the Arctic used for deriving stratospheric $\mathrm{BrO}_{\mathrm{VCD}}$ : (a) stratospheric $\mathrm{NO}_{2} \mathrm{VCDs}$ $\left(\right.$ molec $\mathrm{cm}^{-2}$ ) from QA4ECV (GOME, SCIAMACHY and GOME-2A) and TEMIS (GOME-2B), (b) $\mathrm{O}_{3}$ VCDs (Dobson units) from Weber et al. (2013), and (c) tropopause height $(\mathrm{km})$ from NCEP reanalysis data. Data for the GOME instrument are colored in red, SCIAMACHY in blue, GOME-2A in green and GOME-2B in brown. All three time series show daily averages over the Arctic region ( $\left.>70^{\circ} \mathrm{N}\right)$.

sensing instruments and has a very high spatial resolution of $12.5 \mathrm{~km} \times 12.5 \mathrm{~km}$, while its temporal resolution is $7 \mathrm{~d}$.

\section{Results}

The passive remote sensing spectrometers GOME, SCIAMACHY, GOME-2A and GOME-2B measure the upwelling reflectance at the top of the atmosphere. The months of October to February have few or no observations due to polar night in the target latitudes north of $70.0^{\circ} \mathrm{N}$. The largest solar zenith angle (SZA) used is $80^{\circ}$. The long-term analysis of $\mathrm{BrO}$ columns was performed during the period from March until September, from 1996 to 2017. This period has the best coverage by the ultraviolet-visible (UV-VIS) satellite remote passive sensors at high latitudes. The analysis is restricted to data northwards of $70.0^{\circ} \mathrm{N}$, which is referred to as the Arctic. This region was chosen because the source regions of bromine explosions and thus plumes of elevated $\mathrm{BrO}$ are known to be associated with regions of sea ice cover. We present the derived $\mathrm{BrO}$ VCD time series for the Arctic region, together with corresponding annual cycles, scatterplots and map plots in Sect. 4.1. The tropospheric BrO is corre-
Table 3. Fitting windows used for the different instruments.

\begin{tabular}{ll}
\hline Instrument & Fitting window $(\mathrm{nm})$ \\
\hline GOME & $336.8-358$ \\
SCIAMACHY & $336-347$ \\
GOME-2A & $337.5-357$ \\
GOME-2B & $338-360$ \\
\hline
\end{tabular}

lated with sea ice coverage and age in Sect. 4.2 to investigate the impact of changing sea ice conditions on $\mathrm{BrO}$ amounts in the Arctic's troposphere. Finally, a trend analysis of tropospheric $\mathrm{BrO}$ is performed together with a check for statistical significance of the trends (Sect. 4.3).

\subsection{Comparison between the BrO columns retrieved from different sensors}

The geometric $\mathrm{BrO} \mathrm{VCD}$ is retrieved by dividing the $\mathrm{BrO}$ SCD with a simple stratospheric AMF, which takes into account the scattering at the surface but ignores the impact of scattering within the atmosphere. Consequently, it necessar- 
ily differs from the sum of the tropospheric and stratospheric column. Daily values of the geometric, stratospheric and tropospheric $\mathrm{VCDs}$ of $\mathrm{BrO}$ over the Arctic region are shown in Fig. 3.

The geometric VCD accounts for the expected differences between the different viewing geometries of the satellite sensors to a good first order. There is good agreement during periods of overlapping measurements, e.g., between the retrieved geometric BrO VCD from GOME and SCIAMACHY (from August 2002 to June 2003), SCIAMACHY and GOME-2A (from March 2007 to March 2012), and finally GOME-2A and GOME-2B (from March 2013 to September 2017). A quantitative comparison is provided below. The stratospheric BrO VCDs show a small upward trend from 1995 to 2001 and a slight decrease afterwards, which are in agreement with measurements of stratospheric $\mathrm{BrO}$ from Harestua station (Hendrick et al., 2008).

The comparison of tropospheric BrO VCD time series during the periods of overlap between the different instruments shows a similar level of agreement to that of the geometric VCDs. The seasonality of the tropospheric time series is also similar to the geometric one. We attribute this seasonality to be in large part a result of the inorganic release of $\mathrm{Br}_{2}$ and $\mathrm{BrCl}$ from sources, which depend on sea ice and meteorological parameters. As described in the introduction, in polar spring, the combination of low-temperature conditions on first-year sea ice, having sufficient brine, triggers the release of $\mathrm{Br}_{2}$ and $\mathrm{BrCl}$ into the troposphere. This condition prevails in spring, moving slowly northwards with the solar zenith angle. During July and August, the temperature reaches its maximum. In September, the minimum sea ice extent is observed. The release of organobromine compounds from the oceanic biosphere is hence expected to be highest in summer and early autumn. This provides a biogenic source of bromine, but the oxidation of organic-bromine-containing compounds is relatively slow compared to the release of $\mathrm{BrO}$ from bromine explosion events. During summer and early autumn, tropospheric BrO VCDs reach their minimum values of the year. A small increase is observed in each September. The origin of this increase is not yet identified. Potential candidate explanations include inaccuracies in the stratospheric BrO VCD calculation or potentially lower temperature accelerating the inorganic release of bromine from brine without reaching the threshold for explosion.

We identify peaks in the tropospheric BrO VCD time series: 2007, 2013 and 2015 are the years with the highest tropospheric BrO VCDs in polar spring. Hollwedel et al. (2004) investigated the period from 1996 to 2001. Despite the different settings and cross sections used in the retrieval, their geometric VCDs have similar magnitudes and patterns to those presented here (i.e., they increase from 1997 to 1998 and then decrease from 1999 to 2000). It is also interesting to compare the results from this study with those from Choi et al. (2018). They used the operational product of the OMI (from 2005 to 2015) and the same stratospheric separa- tion method as applied here. In agreement with our findings, Choi et al. (2018) found a peak in tropospheric BrO VCDs in 2007. However, the OMI dataset does not show the same increase as the SCIAMACHY and GOME-2A data in later years. The origin of this difference is not identified. It may be due in part to the strong row anomaly affecting the OMI data product (Class et al., 2010).

Figure 4 shows scatterplots of geometric and tropospheric VCDs for the three overlapping time periods of the instruments.

The best agreement is found between SCIAMACHY and GOME-2A, both for the geometric and the tropospheric VCDs, while the agreement is poorer between GOME and SCIAMACHY (this is attributed to the comparably short overlapping period between these sensors).

Climatological seasonal cycles (averages over the whole period of retrievals of geometric, stratospheric and tropospheric VCDs) for each instrument are shown in Fig. 5.

The annual cycles of the geometric and the tropospheric VCD time series are similar in shape. The largest VCDs occur for all instruments in polar spring (March to May), followed by a strong decrease from May to June. In spring, GOME-2B VCDs are slightly larger, while GOME columns are slightly lower than data from the other instruments for the geometric VCDs. In summer and early autumn GOME VCDs are higher. For the tropospheric VCDs, the differences between the instruments become smaller.

Figure 6 shows average maps of geometric VCDs of $\mathrm{BrO}$ over the Arctic for the overlapping periods of the sensors.

Retrieved geometric $\mathrm{BrO}$ VCDs occur in similar locations and are of similar magnitude to the different instruments. A qualitative comparison of geometric $\mathrm{BrO}$ VCDs between this study and the one by Hollwedel et al. (2004) shows good agreement, with plumes of $\mathrm{BrO}$ being of similar magnitude and appearing over the same locations.

Figure 7 shows the evolution of tropospheric $\mathrm{BrO} \mathrm{VCD}$ maps over the Arctic over $4 \mathrm{~d}$ of selected bromine explosion events - one event for each overlap period of the different sets of sensors.

Bromine explosion events are characterized by high values of tropospheric BrO VCDs, which occur every polar spring. The agreement between the tropospheric BrO VCDs retrieved from the different sensors is good, as shown above. $\mathrm{BrO}$ plumes appear over the same areas and have similar magnitudes for each bromine explosion case. The times of observations are similar but not identical, and we have not identified evidence of this influencing the comparison of tropospheric BrO VCDs. The sensors also observe the transport of plumes of $\mathrm{BrO}$ by cyclones away from the initial release area (e.g., the 2007 case shown in Fig. 5, investigated in more detail by Begoin et al., 2010). Hence, the track of cyclones transporting $\mathrm{BrO}$ plumes is expected to influence longer-term averaged $\mathrm{BrO}$ maps. 

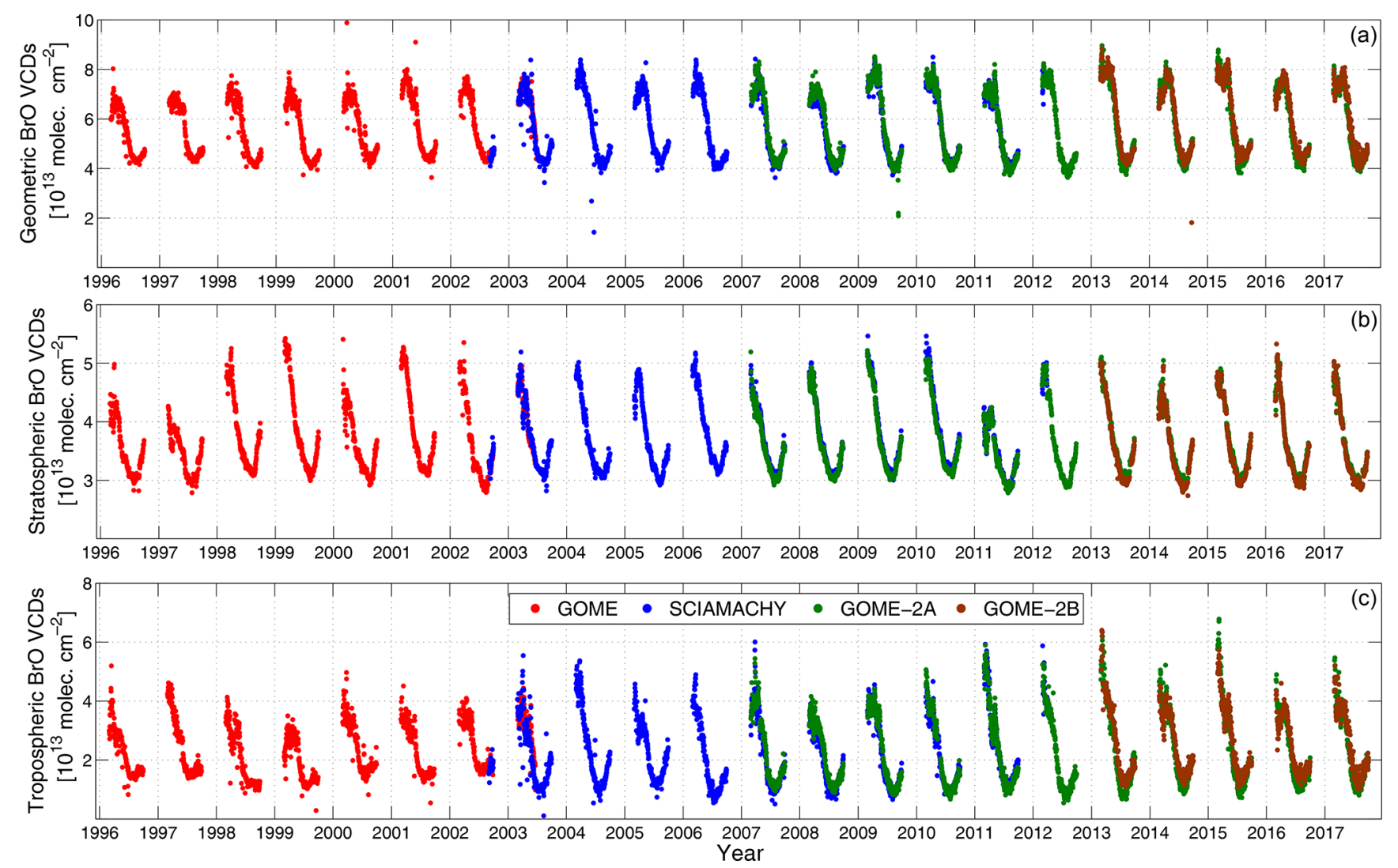

Figure 3. Long-term $\mathrm{BrO}$ time series over the Arctic region: (a) daily geometric $\mathrm{BrO}$ VCDs $\left(10^{13} \mathrm{molec} \mathrm{cm}^{-2}\right)$, (b) daily stratospheric $\mathrm{BrO}$ VCDs $\left(10^{13}\right.$ molec $\left.\mathrm{cm}^{-2}\right)$ and (c) daily tropospheric BrO VCDs $\left(10^{13}\right.$ molec $\left.\mathrm{cm}^{-2}\right)$. All figures show daily averages $\geq 70.0^{\circ} \mathrm{N}$. GOME data are colored in red, SCIAMACHY in blue, GOME-2A in green and GOME-2B in brown.

\subsection{Arctic tropospheric $\mathrm{BrO}$ and its relationship to sea ice}

In this section, the evolution of tropospheric $\mathrm{BrO}$ and its relation to sea ice is presented. More specifically, the relationship between first-year ice and tropospheric $\mathrm{BrO}$ is investigated. Since an albedo of 0.9 was assumed in the tropospheric AMF, a sea-ice-based ground scene flagging of our tropospheric $\mathrm{BrO}$ dataset was performed. In this way, only $\mathrm{BrO}$ observations above sea ice are analyzed. $\mathrm{BrO}$ plumes are also transported over the ocean, but in this study, we focus on the plumes created by bromine explosions over sea ice. As described in Sect. 4.1, the individual BrO VCD time series from the four sensors are highly consistent, and the remaining inconsistencies are small. Hence, a merged tropospheric $\mathrm{BrO}$ dataset over sea ice was retrieved by averaging the overlapping days between the sensors. The merged tropospheric $\mathrm{BrO}$ VCD dataset is shown in Fig. 8 together with the results from the individual sensors and the time series of sea ice extent from Tschudi et al. (2019).

By comparing Figs. $8 \mathrm{~b}$ and $3 \mathrm{c}$, it is found that bromine explosion events are becoming more evident (for example in years 2007 and 2015) if we apply the sea ice flagging (i.e., keeping only scenes with sea ice coverage).

In order to investigate the spatial evolution of tropospheric $\mathrm{BrO}$ in time and its relationship to sea ice age, polar spring (March to May) average maps of tropospheric BrO and corresponding sea ice age maps are displayed in Fig. 9 for each year between 1996 and 2017.

In the past two decades, the area covered by multiyear ice has decreased, and that covered by first-year ice has increased. The elevated levels of $\mathrm{BrO}$ are predominantly found over first-year ice. The magnitude of the elevated $\mathrm{BrO}$ plumes has generally increased, with the maximum occurring in the years 2013 to 2015. In addition, the area in which bromine explosion events occur in the March to May period has changed over the years. For example, from 2010 and onwards, $\mathrm{BrO}$ is formed at the eastern coastline of Greenland comparatively at lower latitudes and inside the Arctic Ocean at higher latitudes (larger than $80.0^{\circ} \mathrm{N}$ ), something not evident in the early years (i.e., 1996 to 2001). In addition, from 2001 to 2003, most of the $\mathrm{BrO}$ is found in the region of the Barents and Kara Sea (to the north of Scandinavia and Russia). However, from 2009 onwards, $\mathrm{BrO}$ plumes have spread over the Arctic region. 

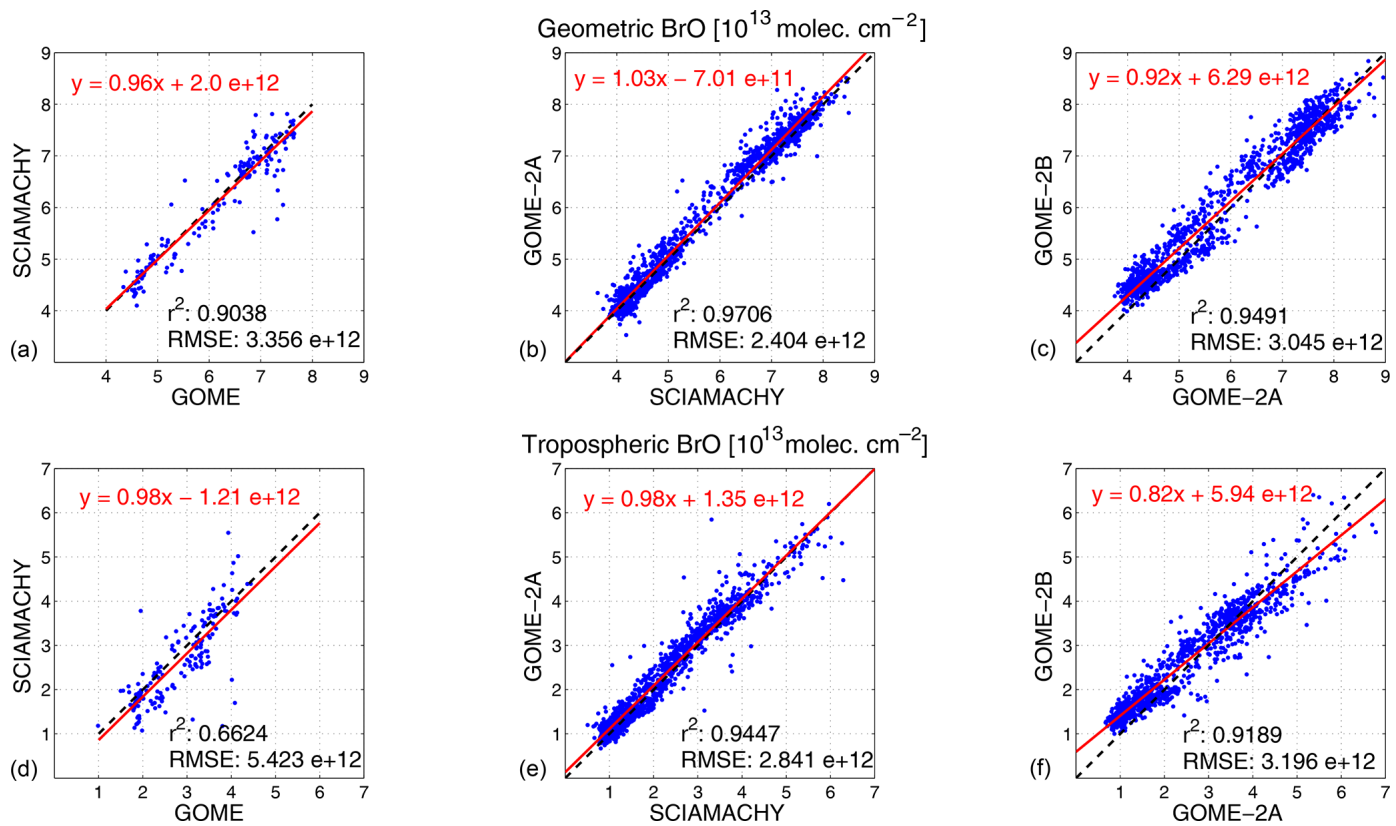

Figure 4. Scatterplots of $(\mathbf{a}, \mathbf{b}, \mathbf{c})$ geometric BrO VCDs and $(\mathbf{d}, \mathbf{e}, \mathbf{f})$ tropospheric BrO VCDs for (a, d) GOME against SCIAMACHY (August 2002 to June 2003), (b, e) SCIAMACHY against GOME-2A (March 2007 to March 2012) and (c, f) GOME-2A against GOME-2B (March 2013 to September 2017). The dashed black line in each scatterplot is the reference line, and the red one is the linear regression line. The Pearson correlation coefficient (squared, $r^{2}$ ), the RMSE and the $y$ function of the regression line are also given. The units for all scatterplots are $\left(10^{13} \mathrm{molec}^{-2}\right)$.
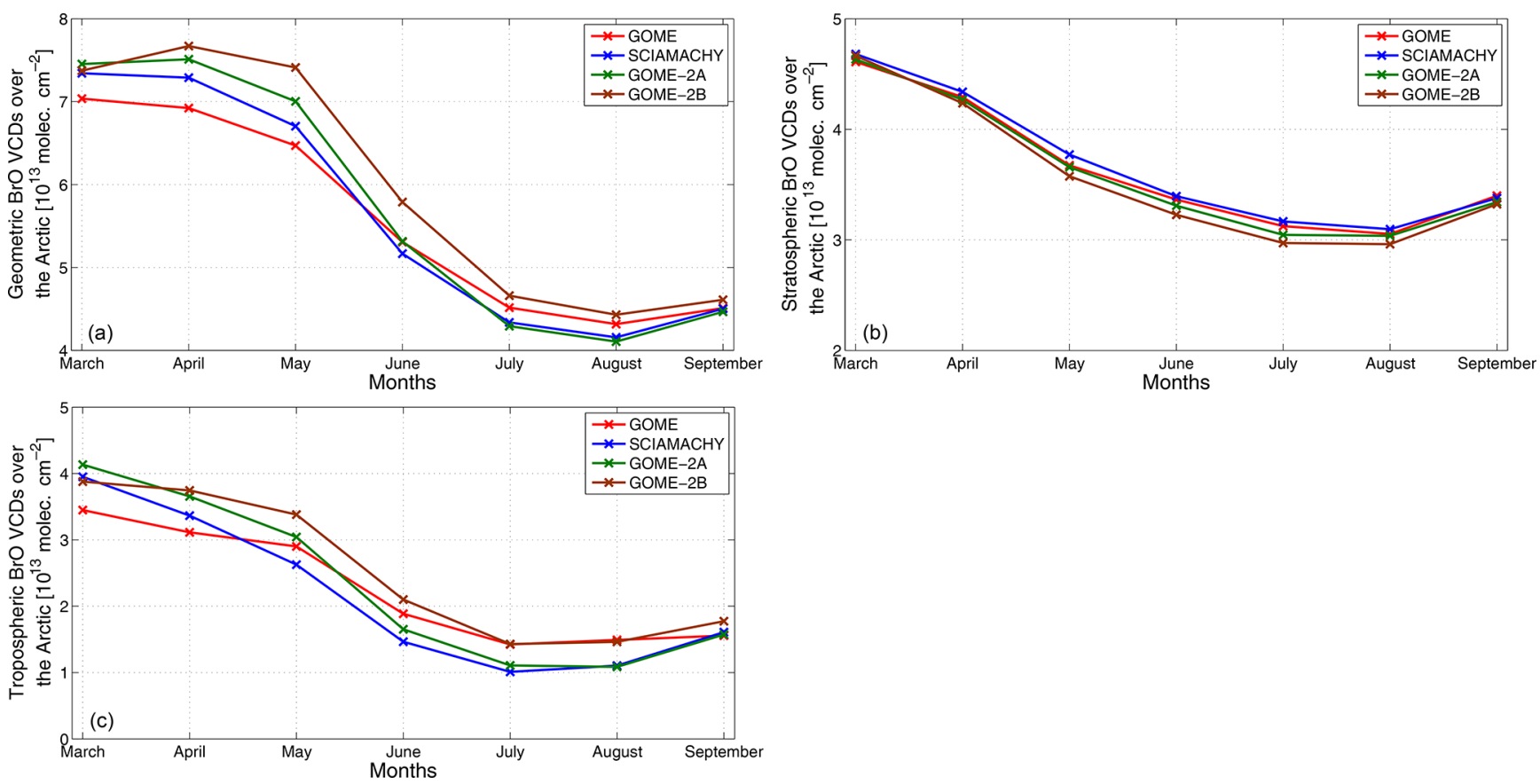

Figure 5. Climatological seasonal cycles of (a) geometric BrO VCDs $\left(10^{13} \mathrm{molec} \mathrm{cm}^{-2}\right)$, (b) stratospheric BrO VCDs $\left(10^{13} \mathrm{molec}^{-2}\right)$ and (c) tropospheric BrO VCDs $\left(10^{13}\right.$ molec $\mathrm{cm}^{-2}$ ) over the Arctic for GOME (red), SCIAMACHY (blue), GOME-2A (green) and GOME2B (brown). 

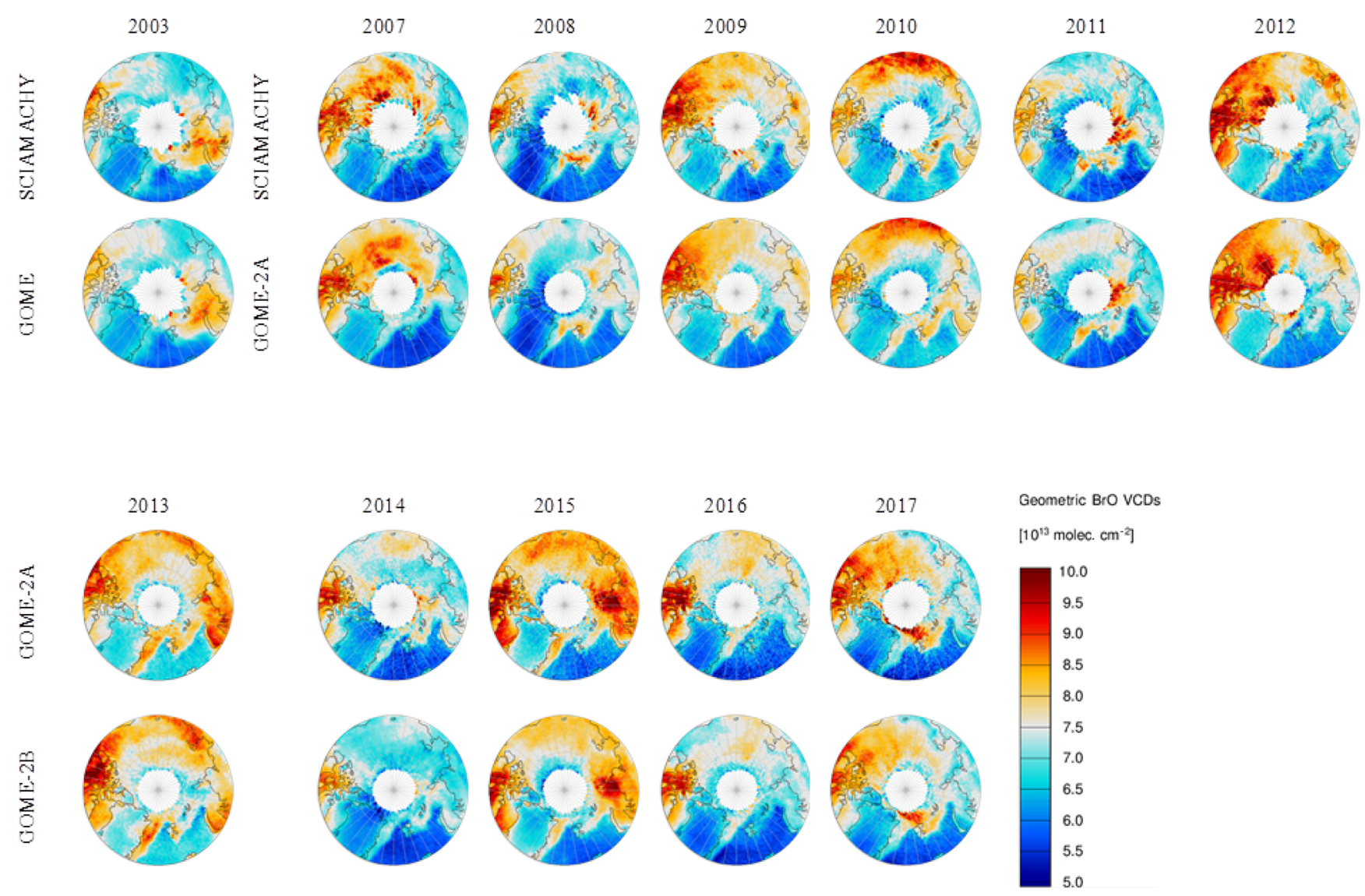

Figure 6. Monthly mean for March of geometric BrO VCDs $\left(10^{13}\right.$ molec $\left.\mathrm{cm}^{-2}\right)$, in the Arctic region. Rows indicate different instruments, while columns indicate different years of overlapping periods of measurements.

First-year ice has become more dominant over the Arctic region in recent years (i.e., 2009 onwards). The year 2009 was the first year for which large tropospheric BrO VCDs were evident over the Canadian Arctic Archipelago and the Beaufort Sea. In 2009, the area of multiyear ice decreased significantly in these regions. Similarly, the appearance of $\mathrm{BrO}$ plumes over the northwest coast of Greenland in 2015 is in agreement with the appearance of first-year ice during this year. The relationship between first-year ice and $\mathrm{BrO}$ VCD is not straightforward or linear but apparent in all years. We attribute the behavior to $\mathrm{BrO}$ sources, conditions at the surface of potential frost flowers, blowing snow and cold brine, and the transport of air masses in which bromine explosions are occurring. In 2004, for example, the highest BrO VCDs are found over a multiyear ice area, whereas in $2002 \mathrm{BrO}$ is mainly seen over first-year ice. The increase in magnitude of $\mathrm{BrO}$ plumes is not simply related to the development of first-year ice as identified in the maps above. In summary, the increase in the areas where tropospheric bromine explosions occur is related in a nonlinear way to the increase in first-year-ice-covered Arctic regions.
Figure 10 shows yearly anomaly polar spring maps of tropospheric $\mathrm{BrO}$ VCDs with respect to the 22 -year mean. The 22-year average is shown in the last row of the figure.

During the first years of the time series, BrO VCDs are lower than on average in most regions of the Arctic. The first large positive anomaly compared to the mean occurs in 2009 and in areas where first-year ice appeared for the first time.

From 2011 onwards, BrO VCDs grow in the north and to the east of Greenland. When comparing the last with the first 5 years of the time series, BrO VCDs have increased.

Figure 11 shows plots that probe the relationship between tropospheric $\mathrm{BrO}$ and first-year ice extent. More specifically, Fig. 11a shows a plot of the polar spring tropospheric BrO VCD above first-year ice and first-year ice extent, and Fig. 11b shows the area of ice where the tropospheric $\mathrm{BrO}$ VCD exceeds a threshold of $7 \times 10^{13}$ molec $\mathrm{cm}^{-2}$. This threshold value was chosen empirically, as in previous studies (Hollwedel et al., 2004; Choi et al., 2018). First-year ice extent and corresponding scatterplots are also given. For the time series of this figure, all the polar spring values north of $70^{\circ} \mathrm{N}$ for each year were averaged, thereby deriving one value per year. 

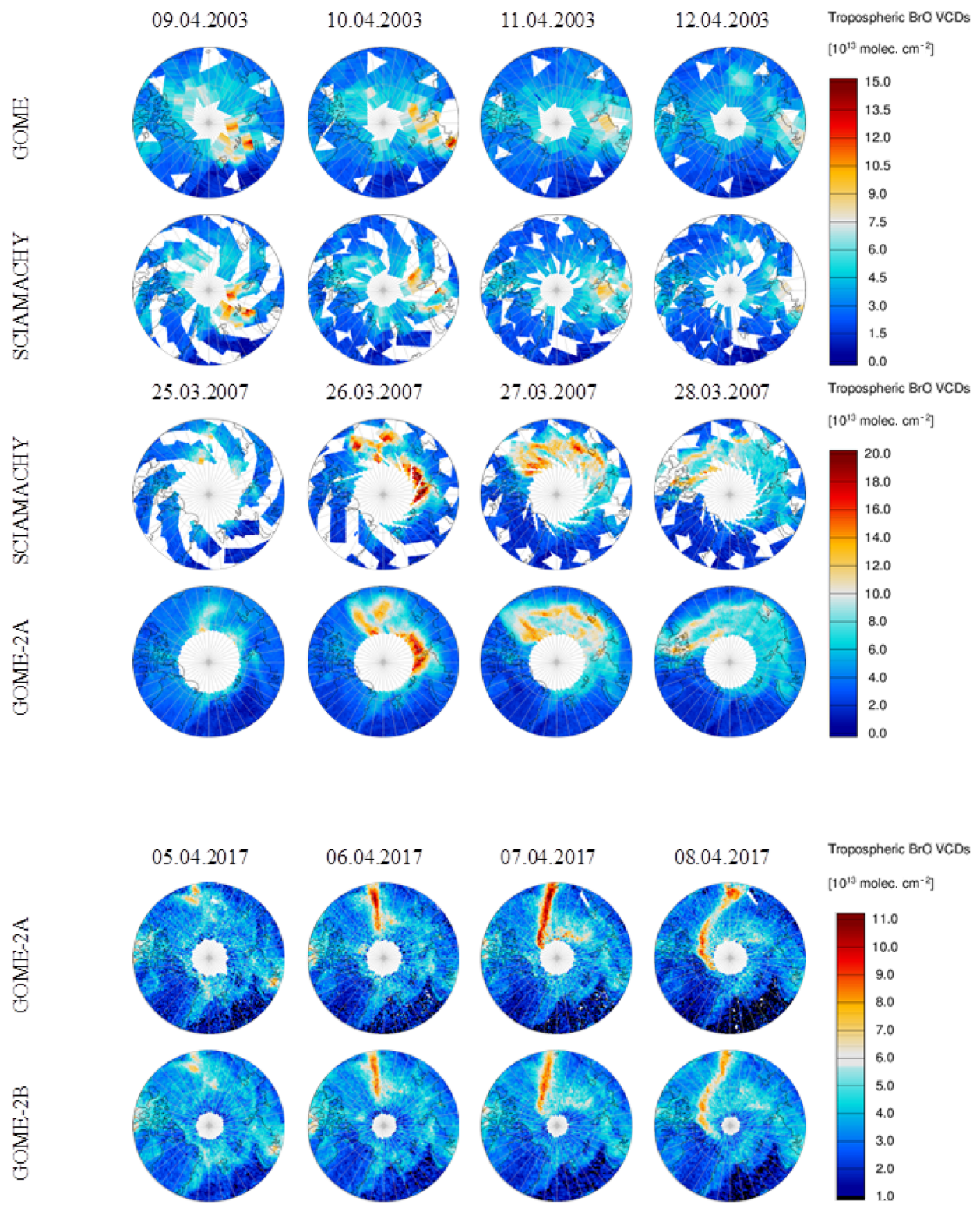

Figure 7. Examples of bromine explosion events over the Arctic region for overlapping measurement periods between the sensors. Rows refer to the different instruments, whereas columns refer to the dates. For each case, four daily average maps of tropospheric BrO VCD $\left(10^{13}\right.$ molec $\left.^{-2}\right)$ are shown.

The total Arctic sea ice extent has decreased over the last years, but the area covered by first-year sea ice has increased. The type of ice encountered at the surface is changing. Due to the increasing temperatures in the Arctic, more sea ice now melts every year, and more first-year or young sea ice is formed each winter period. Figure 11a shows that 2008 was the first year that first-year ice extent exceeded the threshold of $5 \times 10^{6} \mathrm{~km}^{2}$, which is also the case for almost all of the following years. The first-year ice extent in spring (i.e., the area of first-year ice in the months March until May) for the decade 2007 to 2017 is larger than that from 1996 to 2006. Although tropospheric BrO VCDs have also increased in magnitude approximately from 2007 onwards, $\mathrm{BrO}$ VCD and sea ice area do not correlate strongly. In the years 2008 and 2016, a decrease in tropospheric BrO VCDs, when compared to 2007 and 2015, respectively, is found, while first-year ice extent increased. In 2015, the highest tropospheric $\mathrm{BrO} \mathrm{VCD}$ polar spring averages are found. In the same year, the polar spring first-year sea ice extent average has its lowest value after 2008. Similar conclusions can be drawn from Fig. 11c. Although most days of average $\mathrm{BrO}$ above $7 \times 10^{13}$ molec $\mathrm{cm}^{-2}$ are occurring with first-year ice extent above $4.5 \times 10^{6} \mathrm{~km}^{2}$, we can see such days also below this threshold. The positive correlation coefficient between 


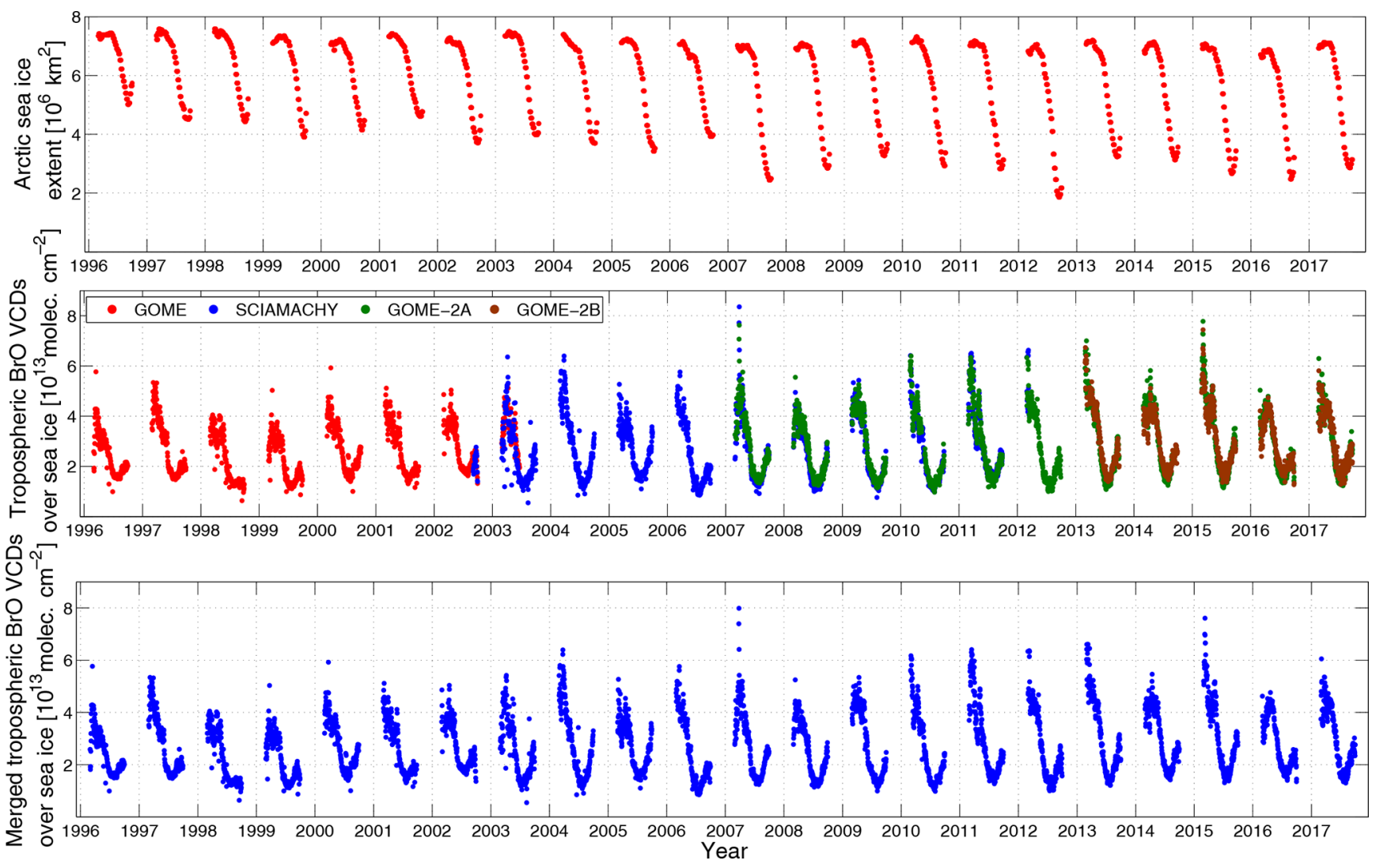

Figure 8. (a) Arctic sea ice extent from March until September from Tschudi et al. (2019); (b) tropospheric BrO VCDs above sea ice in the Arctic (GOME data are shown in red, SCIAMACHY in blue, GOME-2A in green and GOME-2B in brown); and (c) the sensor merged tropospheric BrO VCDs above sea ice in the Arctic.

polar spring tropospheric BrO VCDs and first-year sea ice extent for the same period is 0.32 with an error of 0.021 . The significance of the correlation was verified by performing a significance test, based on the $p$ values. The null hypothesis (there is no correlation between the two quantities) was rejected, as the $p$ value was $<0.05$. Therefore the significance test was successful, meaning there is a correlation between tropospheric $\mathrm{BrO}$ and sea ice age (although, based on the actual value of the correlation coefficient, it is moderate). The correlation between areas of enhanced tropospheric $\mathrm{BrO}$ VCDs and first-year ice extent is lower, approximately 0.2 with an error of 0.022 . This is evident from both the time series (Fig. 11b) and their scatterplot (Fig. 11d, bottom right). In this case, the significance test was not successful, i.e., there is not a correlation between areas of BrO VCDs $>7 \times 10^{13} \mathrm{molec}^{-2}$ and first-year ice extent. We have also calculated correlation coefficients for the annual time series (Fig. 11a and b). In this case, the correlation coefficient between tropospheric BrO VCDs and sea ice extent is 0.62 and for the area of BrO VCDs $>7 \times 10^{13} \mathrm{molec} \mathrm{cm}^{-2}$ and firstyear ice extent 0.46 . However, since these calculations are based on only 22 values, they are statistically less important than the correlation coefficients calculated based on the daily time series. It seems that, in both cases, the largest number of days with high tropospheric BrO VCDs or largest areas of bromine explosion events are occurring when first-year ice extent is between $4.5 \times 10^{6}$ and $5 \times 10^{6} \mathrm{~km}^{2}$ and not when it reaches its peak. The magnitude of tropospheric $\mathrm{BrO}$ VCDs is positively and significantly but not strongly related to firstyear ice extent. This conclusion is consistent with a strongly nonlinear bromine explosion mechanism dependent on more than one key parameters. This finding is in contrast to the results by Choi et al. (2018), where an analysis of BrO VCD retrieved from the OMI was performed. They found a correlation coefficient of -0.32 between first-year ice extent and tropospheric bromine explosion frequency. The negative sign is attributed to a decrease in tropospheric BrO VCDs over the latter years of the trend analysis. The differences to Choi et al. (2018) may be explained by a degradation of the OMI (Kroon et al., 2011).

\subsection{Trend analysis}

A trend analysis of the tropospheric $\mathrm{BrO}$ VCD time series is performed in order to investigate the statistical significance of the observed temporal and spatial changes in tropospheric 

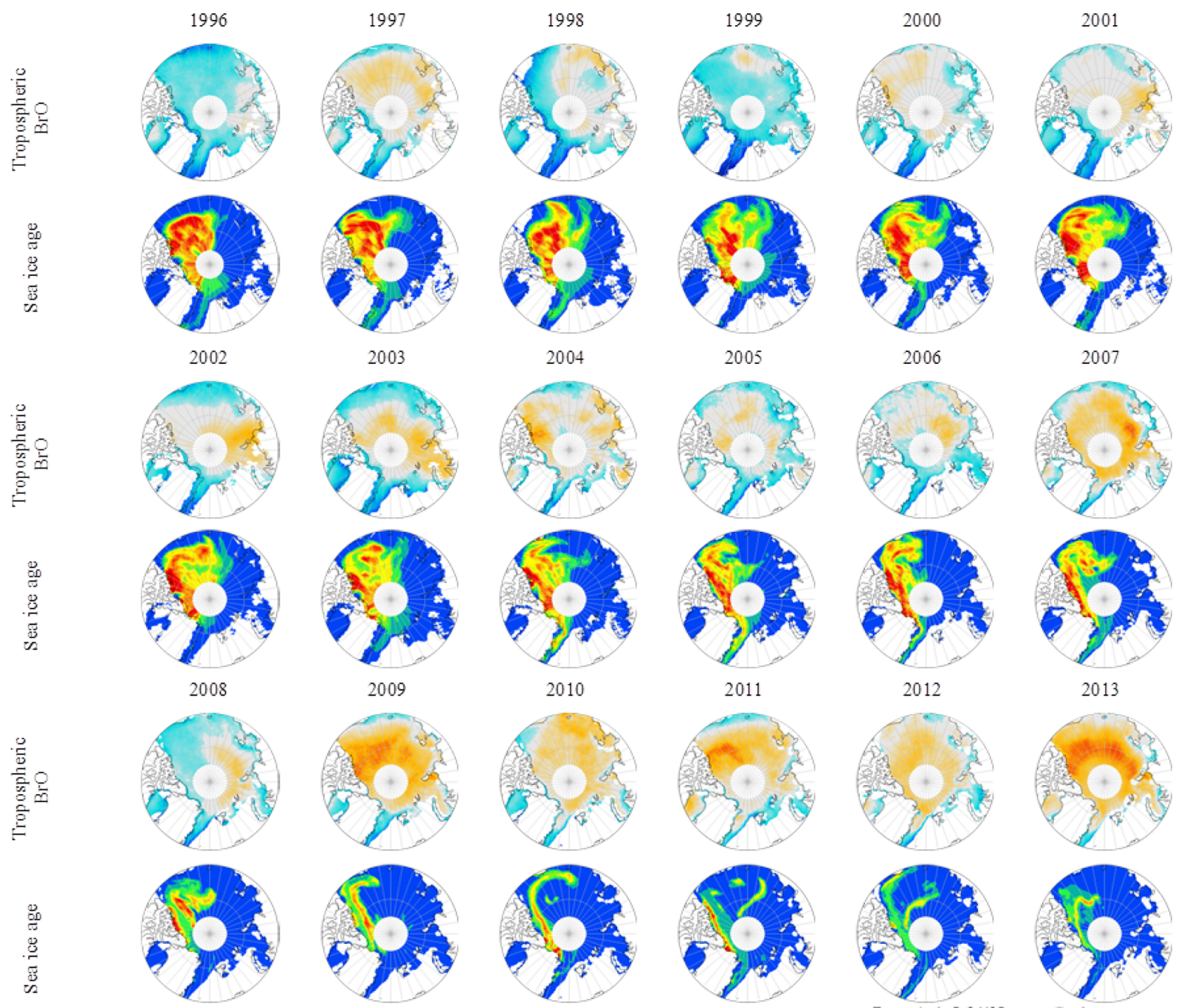

2011

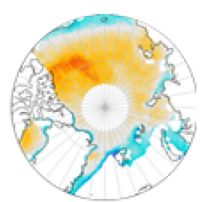

2012
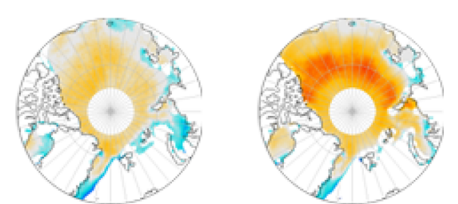

2014
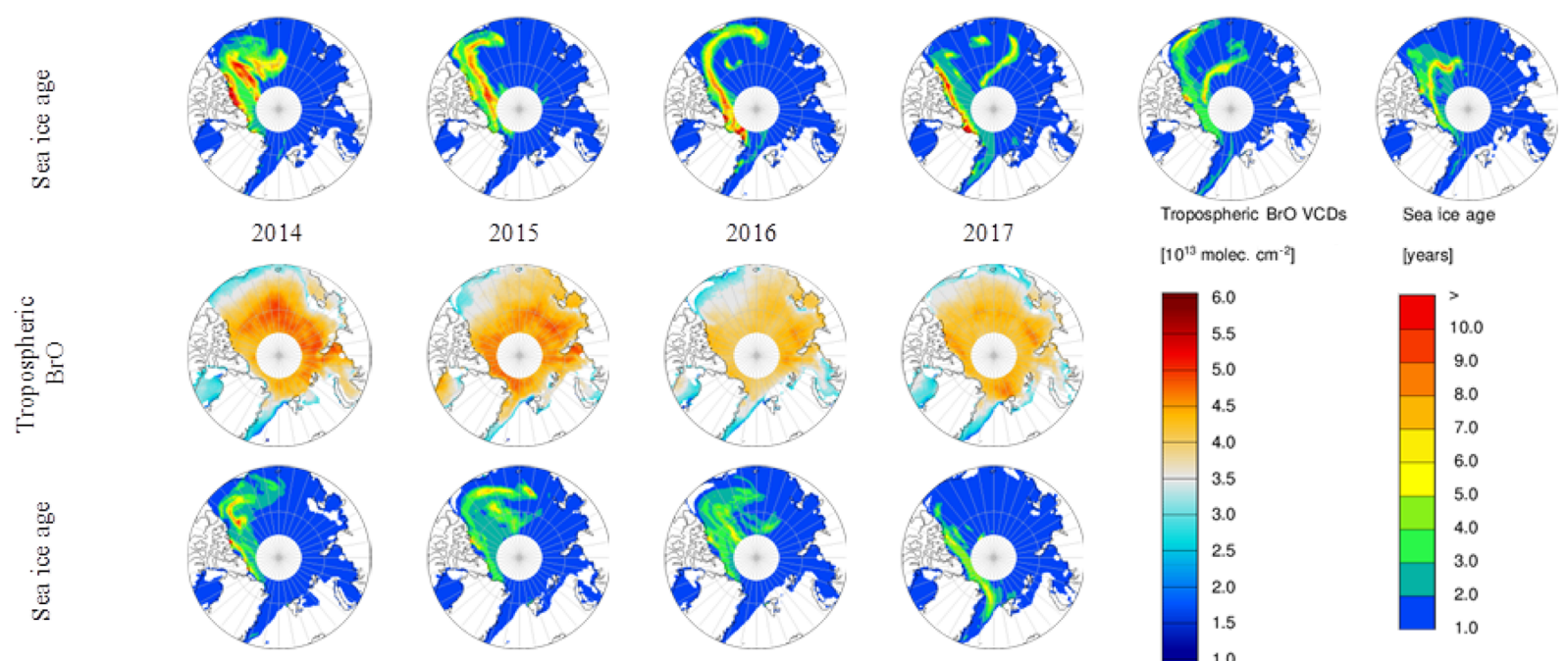

Figure 9. Polar spring (March, April and May, MAM) averages of tropospheric BrO VCDs $\left(10^{13}\right.$ molec $\left.\mathrm{cm}^{-2}\right)$ over sea ice, compared to sea ice age in the Arctic. Columns refer to years, odd rows to tropospheric BrO VCDs and even rows to sea ice age.

$\mathrm{BrO} \mathrm{VCDs}$ associated with the Arctic warming. The tropospheric BrO VCD time series shows a seasonality, with a maximum every polar spring (March in most cases) and a minimum every summer. Consequently, a model which combines a linear trend and seasonal variations is selected, similar to that used in previous studies (Hendrick et al., 2008;
Georgoulias et al., 2019). We calculated trends using Eq. (7):

$$
\mathrm{d}(t)=A t+B+\sum_{i=1}^{3}\left\{C_{i} \cos \left(\frac{2 \pi}{M}(t)\right)+D_{i} \sin \left(\frac{2 \pi}{M}(t)\right)\right\},
$$

where $A$ is the slope, $B$ is the intercept, $\mathrm{d}(t)$ is the modeled value of $\mathrm{BrO} \mathrm{VCD}$ on a given day, $t$ is the day of the dataset 

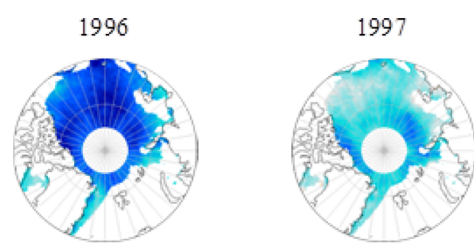

2003

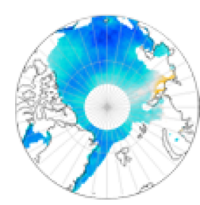

2008

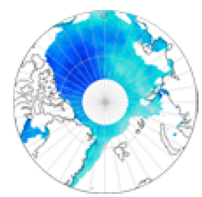

2014

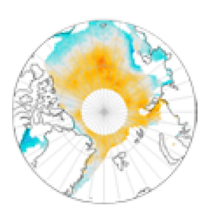

2009

2015

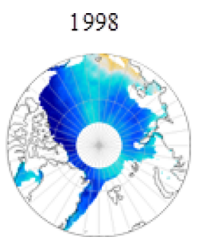

2004
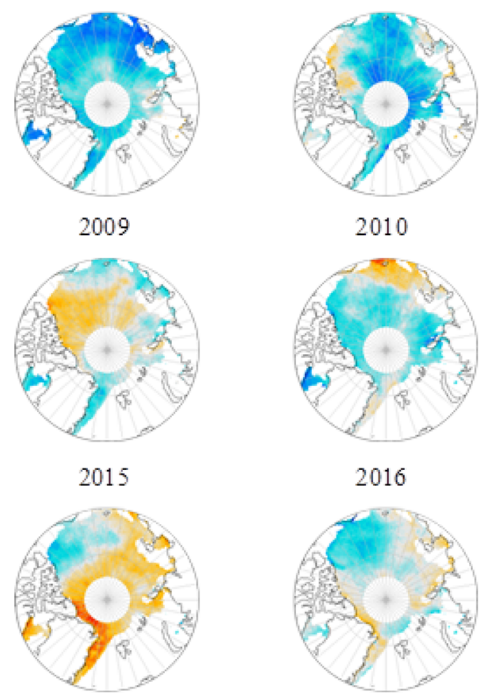

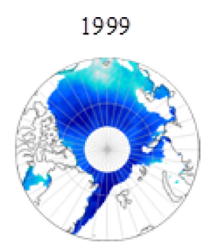

2005

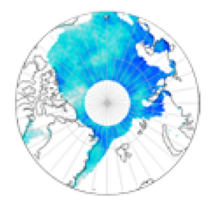

2011

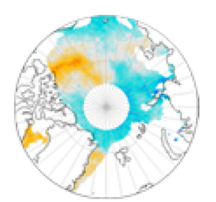

2017

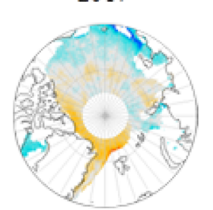

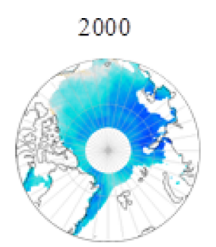

2006

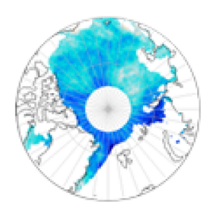

2012

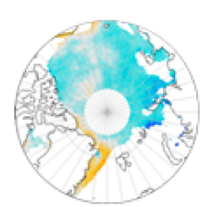

22-year average (1996-2017)

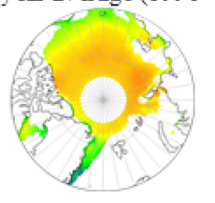

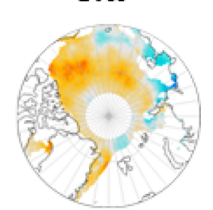

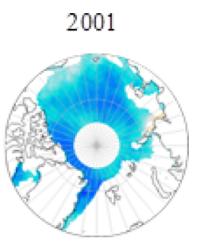

2007

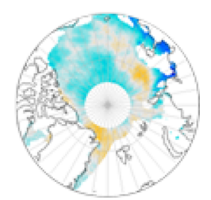

2013

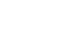

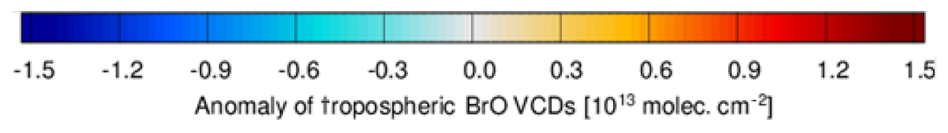

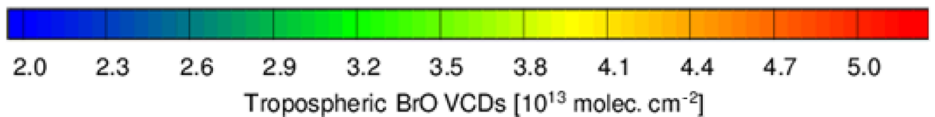

Figure 10. Anomaly maps of polar spring (MAM) tropospheric BrO VCDs $\left(10^{13}\right.$ molec $\left.\mathrm{cm}^{-2}\right)$ over sea ice. From every MAM average, the 22-year average (1996 to 2017, shown at the bottom right of row four) of tropospheric BrO VCDs was subtracted.

(expressed in fractional years) and $M$ is the period in years. The number of harmonic functions was chosen based on the minimization of the residuals between the model and the dataset. The error of each trend was calculated using Eq. (8) (Weatherhead et al., 1998):

$\sigma_{B}=\left[\frac{\sigma_{M}}{M^{3 / 2}} \sqrt{\frac{1+\varphi}{1-\varphi}}\right]$,

where $\sigma_{M}$ is the standard deviation of the residuals between the model and the time series, $M$ is the period in years, and $\varphi$ is the autocorrelation of the residuals (0.2). Finally, a trend is considered significant if the ratio between it and its error is greater than 2 (Weatherhead et al., 1998).

Table 4 shows the trends of tropospheric $\mathrm{BrO}$ over sea ice north of $70^{\circ} \mathrm{N}$ over the whole period (see Fig. 8c), for individual months and for the area of the BrO VCD associated with bromine explosions (Fig. 11b). For the trends of the individual months, we did not use the trend model with har- monics in Eq. (7) and used Eq. (9) instead:

$\mathrm{d}(t)=A t+B$.

The monthly trends in Table 4 with the exception of the trends of the summer months July and August and for the trend of $\mathrm{BrO}$ plumes are statistically significant. The linear trend of the annual tropospheric BrO VCD over the Arctic shows an approximately $1 \%$ increase per year over the last 22 years. During individual polar spring months the increase in $\mathrm{BrO}$ VCD is stronger, reaching a value of $1.5 \% \mathrm{yr}^{-1}$. The trends of BrO VCD during summer months are smaller, and those in July and August are statistically insignificant.

Figure 12 shows the trends appearing in the tropospheric $\mathrm{BrO}$ time series, based on different time periods, i.e., different starting and ending years. Equation (9) was used to calculate the trends, starting from and to the same date for both the starting and the ending years (i.e., end of March).

Linear trends calculated by starting in one year and ending in the next one (e.g., from 1996 to 1997) are in agreement 

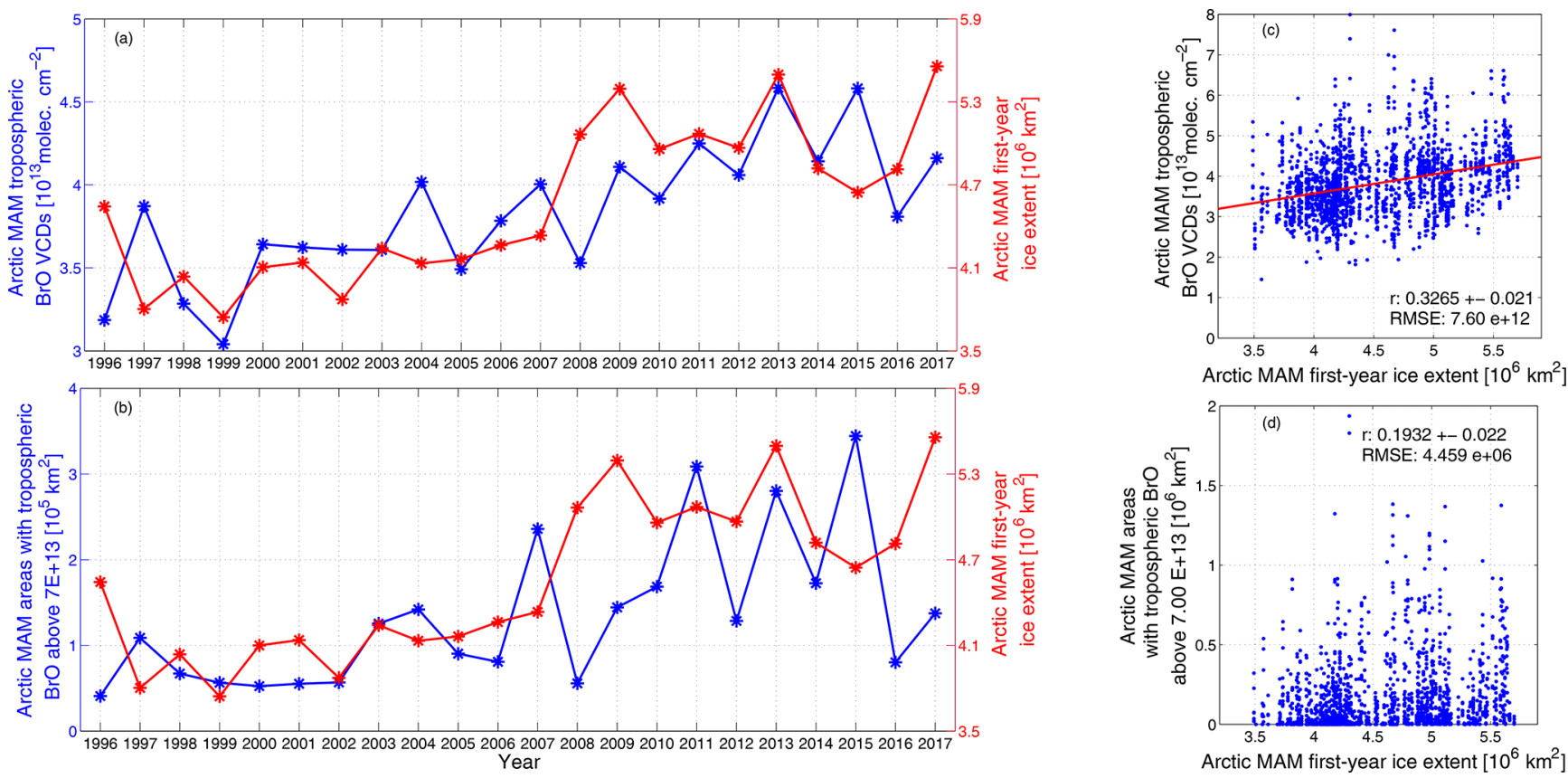

Figure 11. (a) Polar spring (MAM) mean time series of tropospheric BrO VCDs over sea ice and first-year sea ice extent over the Arctic, (b) polar spring (MAM) mean time series of areas with BrO VCDs above the threshold of $7 \times 10^{13}$ molec cm $^{-2}$ and first-year sea ice extent over the Arctic, (c) scatterplots showing polar spring averages of tropospheric BrO VCDs against first-year ice extent, and (d) polar spring averages of areas with tropospheric BrO VCDs exceeding the threshold of $7 \times 10^{13}$ molec cm ${ }^{-2}$ against first-year ice extent in the Arctic. The linear regression lines in (c) and (d) are shown in red in each scatterplot. The Pearson correlation coefficient $(r)$, its error and the root mean square errors (RMSE) between the regression line and plotted quantities are shown in each scatterplot.

Table 4. Trends of tropospheric BrO VCD (over the whole period and for individual months) and for the area of plumes from bromine explosions between 1996 and 2017, together with their errors and significance of each trend. The unit for all quantities is molecules per square centimeter $\left(\right.$ molec $\left.\mathrm{cm}^{-2}\right)$, except the for the area of BrO plumes $\left(\mathrm{km}^{2}\right)$.

\begin{tabular}{|c|c|c|c|c|}
\hline Quantity & $\begin{array}{r}\text { Trend } \\
\text { (units per year) }\end{array}$ & $\begin{array}{r}\text { Error in trend } \\
\text { (units per year) }\end{array}$ & $\begin{array}{r}\text { Trend percentage } \\
\text { (\% per year) }\end{array}$ & Significant \\
\hline Merged BrO VCD (molec $\mathrm{cm}^{-2}$ ) (Fig. 8c) & $+2.4 \times 10^{11}$ & $1.1 \times 10^{11}$ & +0.99 & Yes \\
\hline March BrO VCD (molec $\mathrm{cm}^{-2}$ ) (Fig. 8c) & $+5.2 \times 10^{11}$ & $8.5 \times 10^{10}$ & +1.50 & Yes \\
\hline April BrO VCD (molec $\mathrm{cm}^{-2}$ ) (Fig. 8c) & $+4.9 \times 10^{11}$ & $5.0 \times 10^{10}$ & +1.60 & Yes \\
\hline May BrO VCD (molec $\mathrm{cm}^{-2}$ ) (Fig. 8c) & $+3.9 \times 10^{11}$ & $5.0 \times 10^{10}$ & +1.30 & Yes \\
\hline June $\mathrm{BrO}$ VCD $\left(\right.$ molec $\left.\mathrm{cm}^{-2}\right)($ Fig. $8 \mathrm{c})$ & $+1.5 \times 10^{11}$ & $4.3 \times 10^{10}$ & +0.74 & Yes \\
\hline July BrO VCD (molec $\mathrm{cm}^{-2}$ ) (Fig. 8c) & $+2.9 \times 10^{10}$ & $2.2 \times 10^{10}$ & +0.18 & No \\
\hline August BrO VCD (molec $\mathrm{cm}^{-2}$ ) (Fig. 8c) & $+4.5 \times 10^{10}$ & $3.1 \times 10^{10}$ & +0.26 & No \\
\hline September BrO VCD (molec $\mathrm{cm}^{-2}$ ) (Fig. 8c) & $+2.8 \times 10^{11}$ & $4.3 \times 10^{10}$ & +1.43 & Yes \\
\hline Area of $\mathrm{BrO}$ plumes $\left(\mathrm{km}^{2}\right)$ (Fig. $\left.11 \mathrm{~b}\right)$ & +896 & 2280 & +0.06 & No \\
\hline
\end{tabular}

with the BrO VCD shown in Fig. 8c (for example, the strong positive change from 2014 to 2015 or the decrease from 1997 to 1998). Trends over short periods are dominated by interannual variability. The positive linear trends are largest when the later years are included. We see that the strongest longterm positive trends occur when we choose as a starting point the years 2006-2008 and as an ending point the year 2017.

In Fig. 13, the trend for each individual grid box during polar spring months is displayed for tropospheric $\mathrm{BrO}$, sea ice age and first-year ice frequency occurrence. All three maps are gridded in $0.125^{\circ} \times 0.125^{\circ}$ resolution. The trend for every grid box is calculated using Eq. (9).

Tropospheric BrO VCD values increase inside the region of the Arctic Ocean and also to the north and east of Greenland, where sea ice age shows negative trends. We learned from Fig. 9 that, after 2008, first-year ice appears in the same area. This can also be verified by Fig. 13c, as in the same area we see a positive increase of 2.5 to 3 first-year ice oc- 


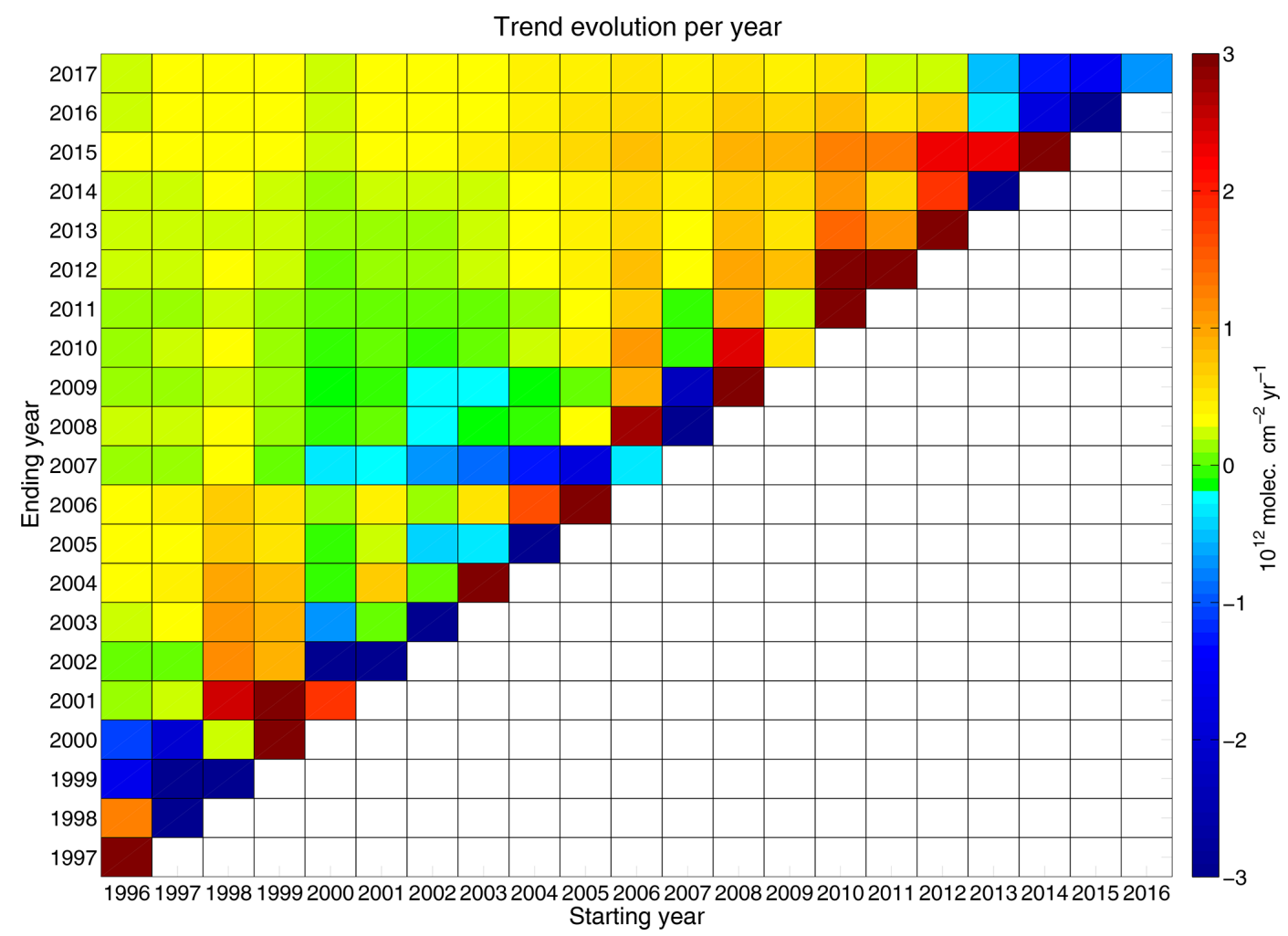

Figure 12. Trend $\left(10^{12}\right.$ molec $\left.\mathrm{cm}^{-2} \mathrm{yr}^{-1}\right)$ evolution of the merged tropospheric BrO dataset (i.e., slope of the linear regression line) over sea ice. The $x$ axis shows the starting year and the $y$ axis shows the ending year of the period over which the trend was calculated.

currences per year. However, the trends of tropospheric $\mathrm{BrO}$ VCD and sea ice age do not match everywhere. The strongest negative trends in the sea ice map occur in areas where multiyear ice was dominant in the past, and first-year ice has formed in the recent years (Beaufort Sea and Canadian Arctic Archipelago). However, in the same area, we do not see the most pronounced increase in the trend map of tropospheric $\mathrm{BrO}$ VCDs (the increase is smaller than in other areas). The strongest increase in tropospheric $\mathrm{BrO}$ VCDs occurs to the northeast of Greenland close to the Fram Strait, to the north of Greenland and close to Ellesmere Island. Although firstyear ice seems to be appearing more frequently in the east of Greenland, we do not see the same evolution on the north side of Greenland. On the contrary, we see a decrease in firstyear ice occurrences over the latest years. Therefore, we can conclude that, although first-year ice has a relation to the increased tropospheric $\mathrm{BrO}$ plumes observed over the recent years, it is not the only parameter affecting the formation of enhanced BrO.

\section{Summary and conclusions}

In this study, a merged dataset of tropospheric $\mathrm{BrO}$ VCD over the Arctic north of $70^{\circ} \mathrm{N}$ retrieved from the measurements of four similar UV-VIS remote sensing satellite instruments over a 22-year time period is presented. A high level of consistency of the retrieved BrO VCDs was found between the retrievals from the different sensors. Time series of tropospheric BrO VCDs over the Arctic north of $70^{\circ} \mathrm{N}$ and corresponding trends indicate that the magnitude of tropospheric BrO VCDs has increased, especially in the decade from 2007 to 2017 , when we observe a 1.23 times stronger increase than from the period 1996 to 2017. This increase is pronounced in polar spring, when the majority of bromine explosion events occur. Additionally, from the spatial patterns of tropospheric $\mathrm{BrO} \mathrm{VCD}$, we infer that the size of the areas of elevated $\mathrm{BrO}$ VCD (i.e., impacted by bromine explosions) has increased about $896 \mathrm{~km}^{2} \mathrm{yr}^{-1}$.

The correlation between tropospheric BrO VCD and sea ice age time series and spatial trends was investigated. The overall increase in tropospheric $\mathrm{BrO} \mathrm{VCD}$ is taking place at the same time as the increase in first-year ice coverage. Dependent on the meteorological conditions, the presence of first-year ice, which has a higher salinity than multiyear ice, facilitates the release of bromine and thus the production of $\mathrm{BrO}$. However, our analysis shows that there are areas where tropospheric $\mathrm{BrO}$ correlates well with first-year sea ice, while in other regions this was not clear. Tropospheric BrO VCD is moderately (correlation coefficient of 0.32 for daily time series and 0.62 for the annual) but significantly correlated with first-year sea ice extent, both temporally and spatially. 
(a)
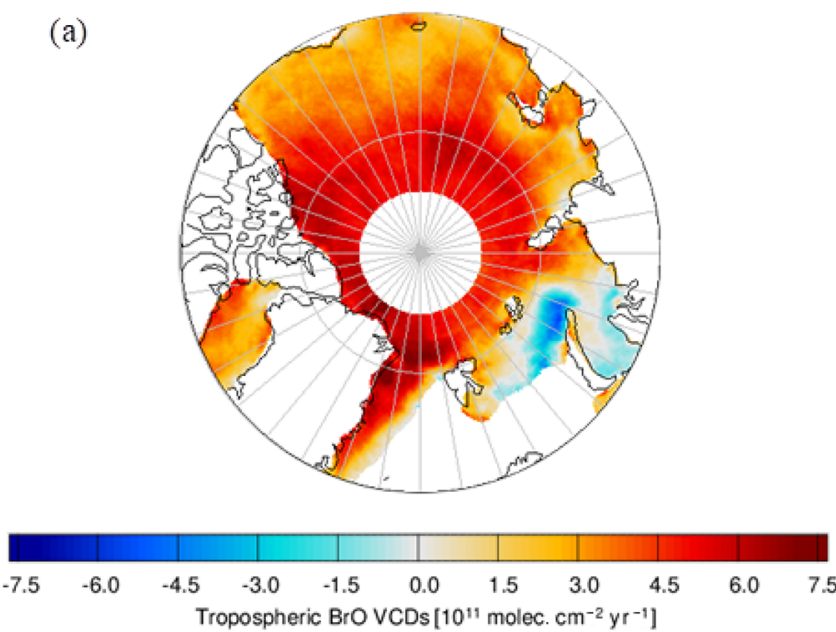

(c)

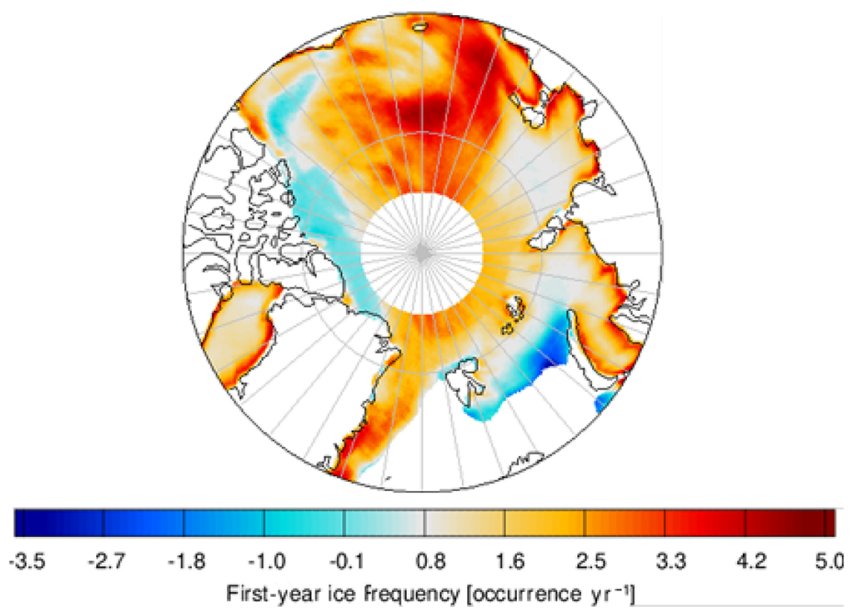

(b)
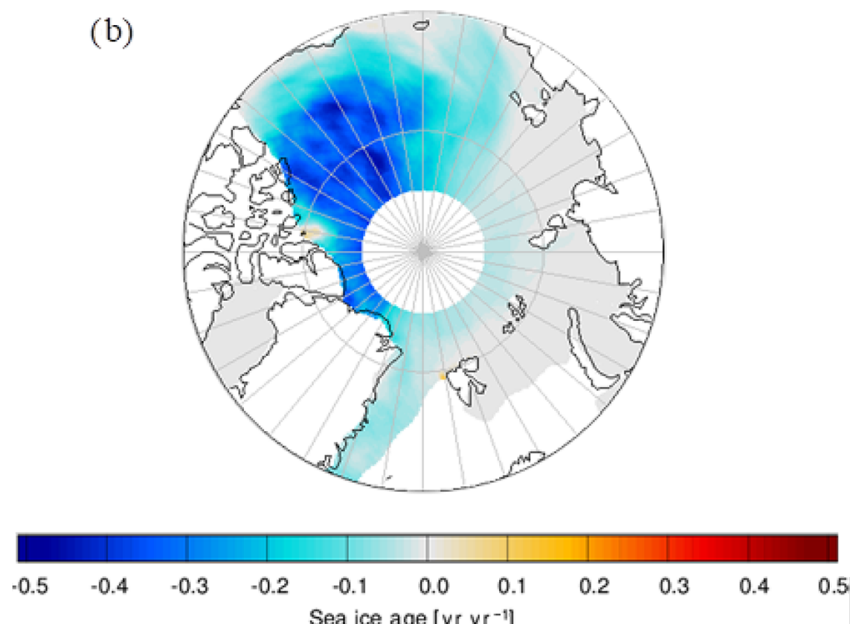

Figure 13. Polar projection of the trend in each grid box $\left(0.125^{\circ} \times 0.125^{\circ}\right)$ during polar spring months (March, April, May, MAM) for (a) tropospheric $\mathrm{BrO}$ VCD over sea ice $\left(10^{11} \mathrm{molec} \mathrm{cm}^{-2} \mathrm{yr}^{-1}\right)$, (b) sea ice age (years per year) and (c) first-year ice frequency (occurrence per year). The trends calculated over a 22 -year period (1996 to 2017).

We suggest that the transport of $\mathrm{BrO}$ plumes away from their source regions complicates the analysis and that the temperature dependence of the bromine explosions induces variability. We infer that the increase in magnitude of $\mathrm{BrO}$ VCD and in the extent of the areas where $\mathrm{BrO}$ plumes appear is linked to the retreat of multiyear ice and the increase in first-year ice in the Arctic region due to the Arctic warming. Although an overall increase in tropospheric $\mathrm{BrO}$ VCDs is found, there is also large interannual variability. While the time series shows a positive trend of approximately $1.5 \% \mathrm{yr}^{-1}$ during polar springs for a period of 22 years (1996 to 2017), tropospheric $\mathrm{BrO}$ decreased during the last 2 years of the time series. It remains to be seen whether the positive trend in tropospheric $\mathrm{BrO}$ VCDs will continue and develop to be more pronounced in future years or decrease as the area of firstyear ice eventually decreases as the Arctic warms.

Yang et al. (2010) investigated ozone loss using numerical modeling and found that blowing snow-sourced bromine reduces tropospheric ozone amounts by up to $8 \%$ in polar spring in the Arctic. The positive trend and interannual variability of tropospheric BrO VCDs reported in the present study would imply increasing but highly variable losses of $\mathrm{O}_{3}$ and deposition of $\mathrm{Hg}$ over the Arctic region, which would also impact the oxidizing capacity of the Arctic atmosphere. The datasets discussed here can be used as a basis to validate $\mathrm{BrO}$ simulations of chemical transport models, in order to quantify this $\mathrm{O}_{3}$ loss, and potential $\mathrm{OH}$ changes. As Arctic warming will continue, tropospheric $\mathrm{BrO}$ abundances will also continue to change. Therefore, the assessment of the impact on $\mathrm{O}_{3}$ depletion is essential.

In addition to sea ice conditions, the appearance of plumes of tropospheric $\mathrm{BrO} \mathrm{VCD}$ and their intensity are influenced by several meteorological drivers (air temperature, sea level pressure, wind speeds and cyclones) and the amounts of blowing snow (Blechschmidt et al., 2016; Seo et al., 2019b). Further investigations are required to understand the evolu- 
tion of tropospheric $\mathrm{BrO}$ and its dependence on these drivers of tropospheric $\mathrm{BrO}$ release. This is required to accurately project changes in tropospheric $\mathrm{O}_{3}, \mathrm{Hg}$ deposition and oxidizing capacity of the Arctic region in a warming Arctic using numerical models.

Data availability. Part of the $\mathrm{BrO}$ data of this study are available through the World Data Center PANGAEA (https://doi. pangaea.de/10.1594/PANGAEA.906046, last access: 7 October 2020, Bougoudis et al., 2019). GOME2 Level 1 data were provided by EUMETSAT. We acknowledge the free use of tropospheric $\mathrm{NO}_{2}$ column data from GOME, GOME-2A, SCIAMACHY and GOME2B sensors from the QA4ECV project (http://www.qa4ecv.eu/, last access: 1 February 2020, Boersma et al., 2017a, b, c) and from the TEMIS website (http://www.temis.nl/index.php, last access: 1 February 2020, Boersma et al., 2004). We acknowledge Mark Weber and the UVSAT group of the Institute of Environmental Physics, University of Bremen, for providing total ozone columns for GOME, SCIAMACHY, GOME2-A and GOME-2B. NCEP Reanalysis data were provided by the NOAA/OAR/ESRL PSD, Boulder, Colorado, USA, through their website (https://www.esrl.noaa. gov/psd/, last access: 1 February 2020, Kalnay et al., 1996). The EASE-Grid Sea Ice Age version 4 was provided by NSIDC from their website (https://nsidc.org/data/nsidc-0611/versions/4, last access: 1 February 2020, Tschudi et al., 2019).

Author contributions. IB undertook the retrieval of $\mathrm{BrO}$ from the different satellite instruments, collected and processed the sea ice age data, performed the analysis, and prepared the paper. This study was initiated by JPB and AMB. The research presented was supervised by AMB, AR and JPB. AMB and NT provided the stratospheric separation. AMB, AR, SS, NT and JPB provided input with respect to $\mathrm{BrO}$ issues of relevance. AR developed software which was used for processing and analyzing the $\mathrm{BrO}$ data. AR provided input on sea ice and trend analyses. All authors contributed to the writing of the paper.

Competing interests. The authors declare that they have no conflict of interest.

Acknowledgements. We thank Francois Hendrick (BIRA-IASB) for his help on $\mathrm{BrO}$ data over Harestua. We thank Christian Melsheimer and the sea ice remote sensing group at the University of Bremen for their help.

Financial support. We gratefully acknowledge the funding by the Deutsche Forschungsgemeinschaft (DFG, German Research Foundation) - project no. 268020496 - TRR 172, within the Transregional Collaborative Research Center "ArctiC Amplification: Climate Relevant Atmospheric and SurfaCe Processes, and Feedback Mechanisms (AC) ${ }^{3}$ ".
The article processing charges for this open-access publication were covered by the University of Bremen.

Review statement. This paper was edited by Neil Harris and reviewed by Robyn Schofield and one anonymous referee.

\section{References}

Afe, O., T., Richter, A., Sierk, B., Wittrock, F., and Burrows, J., P.: BrO emission from volcanoes: A survey using GOME and SCIAMACHY measurements, Geophys. Res. Lett., 31, L24113, doi:10.1029/2004GL020994, 2004.

Akperov, M., Rinke, A., Mokhov, I. I., Matthes, H., Semenov, V. A., Adakudlu, M., Cassano, J., Christensen, J. H., Dembitskaya, M. A., Dethloff, K., Fettweis, X., Glisan, J., Gutjahr, O., Heinemann, G., Koenigk, T., Koldunov, N. V., Laprise, R., Mottram, R., Nikiéma, O., Parfenova, M., Scinocca, J. F., Sein, D., Sobolowski, S., Winger, K., and Zhang, W.: Trends of intense cyclone activity in the Arctic from reanalyses data and regional climate models (Arctic-CORDEX), IOP Conf. Ser.: Earth Environ. Sci., 231, 012003, doi:10.1088/1755-1315/231/1/012003, 2019.

Alvarado, L. M. A., Richter, A., Vrekoussis, M., Wittrock, F., Hilboll, A., Schreier, S. F., and Burrows, J. P.: An improved glyoxal retrieval from OMI measurements, Atmos. Meas. Tech., 7, 4133-4150, https://doi.org/10.5194/amt-7-4133-2014, 2014.

Barrie, L. A., Bottenheim, J. W., Schnell, R. C., Crutzen, P. J., and Rasmussen, R. A.: Ozone destruction and photochemical reactions at Polar sunrise in the lower Arctic atmosphere, Nature, 334, 138-141, 1988.

Barrie, L. and Platt, U.: Arctic tropospheric chemistry: an overview, Tellus B, 49, 450-454, doi:10.3402/tellusb.v49i5.15984, 1997.

Begoin, M., Richter, A., Weber, M., Kaleschke, L., Tian-Kunze, X., Stohl, A., Theys, N., and Burrows, J. P.: Satellite observations of long range transport of a large BrO plume in the Arctic, Atmos. Chem. Phys., 10, 6515-6526, https://doi.org/10.5194/acp10-6515-2010, 2010.

Blechschmidt, A.-M., Richter, A., Burrows, J. P., Kaleschke, L., Strong, K., Theys, N., Weber, M., Zhao, X., and Zien, A.: An exemplary case of a bromine explosion event linked to cyclone development in the Arctic, Atmos. Chem. Phys., 16, 1773-1788, https://doi.org/10.5194/acp-16-1773-2016, 2016.

Boersma, K. F., Eskes, H., Richter, A., De Smedt, I., Lorente, A., Beirle, S., Van Geffen, J., Peters, E., Van Roozendael, M., and Wagner, T.: QA4ECV NO2 tropospheric and stratospheric vertical column data from GOME-2A (Version 1.1) [Dataset], Royal Netherlands Meteorological Institute (KNMI), doi:10.21944/qa4ecv-no2-gome2a-v1.1, 2017a.

Boersma, K. F., Eskes, H., Richter, A., De Smedt, I., Lorente, A., Beirle, S., Van Geffen, J., Peters, E., Van Roozendael, M., and Wagner, T.: QA4ECV NO2 tropospheric and stratospheric vertical column data from SCIAMACHY (Version 1.1) [Dataset], Royal Netherlands Meteorological Institute (KNMI), doi:10.21944/qa4ecv-no2-scia-v1.1, 2017b.

Boersma, K. F., Eskes, H., Richter, A., De Smedt, I., Lorente, A., Beirle, S., Van Geffen, J., Peters, E., Van Roozendael, M., and Wagner, T.: QA4ECV NO2 tropospheric and stratospheric vertical column data from GOME (Version 1.1) 
[Dataset], Royal Netherlands Meteorological Institute (KNMI), doi:10.21944/qa4ecv-no2-gome-v1.1, 2017c.

Boersma, K.F., Eskes, H. J., and Brinksma, E. J.: Error Analysis for Tropospheric NO2 Retrieval from Space, J. Geophys. Res., 109, D04311, doi:10.1029/2003JD003962, 2004.

Bougoudis, I., Blechschmidt, A.-M., Richter, A., Seo, S., and Burrows, J. P.: Climatologies of Geometric and Tropospheric BrO Vertical Column Densities derived from multiple UV-Vis Satellite Remote Sensors for Polar Spring over the Arctic, Institut für Umweltphysik, Universität Bremen, available at: https: //doi.pangaea.de/10.1594/PANGAEA.906046 (last access: 7 October 2020), 2019.

Bovensmann, H., Burrows, J. P., Buchwitz, M., Frerick, J., Noël, S., Rozanov, V. V., Chance, K. V., and Goede, A. P.: SCIAMACHY: Mission Objectives and Measurement Modes, J. Atmos. Sci., 56, 127-150, doi:10.1175/15200469(1999)056<0127:SMOAMM > 2.0.CO;2, 1999.

Bracher, A., Lamsal, L. N., Weber, M., Bramstedt, K., ColdeweyEgbers, M., and Burrows, J. P.: Global satellite validation of SCIAMACHY O3 columns with GOME WFDOAS, Atmos. Chem. Phys., 5, 2357-2368, https://doi.org/10.5194/acp-5-23572005, 2005.

Burrows, J. P., Hölzle, E., Goede, A. P. H., Visser, H., and Fricke, W.: SCIAMACHY-scanning imaging absorption spectrometer for atmospheric chartography, Acta Astronaut., 35, 445-451, doi:10.1016/0094-5765(94)00278-T, 1995.

Burrows, J. P., Platt, U., and Borrell, P. (Eds.): Tropospheric remote sensing from space, in: The remote sensing of tropospheric composition from space, Springer-Verlag, Berlin Heidelberg, 1-65, 2011.

Burrows, J. P., Weber, M., Buchwitz, M., Rozanov, V., LadstätterWeißenmayer, A., Richter, A., DeBeek, R., Hoogen, R., Bramstedt, K., Eichmann, K., Eisinger, M., and Perner, D.: The Global Ozone Monitoring Experiment (GOME): Mission Concept and First Scientific Results, J. Atmos. Sci., 56, 151-175, doi:10.1175/1520-0469(1999)056<0151:TGOMEG > 2.0.CO;2, 1999.

Callies, J., Corpaccioli, E., Eisinger, M., Hahne, A., and Lefebvre, A.: GOME-2 - Metop's second-generation sensor for operational ozone monitoring, ESA Bull.-Eur. Space, 102, 28-36, 2000.

Chance, K. and Kurucz, R.: An improved high-resolution solar reference spectrum for earth's atmosphere measurements in the ultraviolet, visible, and near infrared, J. Quant. Spectrosc. Ra., 111, 1289-1295, 2010.

Chance, K., Kurosu, T. P., and Sioris, C. E.: Undersampling correction for array detector-based satellite spectrometers, Appl. Opt., 44, 1296-1304, 2005.

Choi, S., Theys, N., Salawitch, R. J., Wales, P. A., Joiner, J., Canty, T. P., Chance, K., Suleiman, R. M., Palm, S. P., Cullather, R. I., Darmenov, A. S., Da Silva, A., Kurosu, T. P., Hendrick, F., and Van Roozendael, M.: Link between Arctic tropospheric BrO explosion observed from space and sea salt aerosols from blowing snow investigated using Ozone Monitoring Instrument BrO data and GEOS 5 data assimilation system, J. Geophys. Res.-Atmos., 123, 6954-6983, doi:10.1029/2017JD026889, 2018.

Class, J., Braak, R., and Kroon, M.: OMI Row anomaly, Introduction and flagging, 15th OMI Science Team Meeting, KNMI, De Bilt, Netherlands, 15-17 June 2010, 2010.
Dikty, S, Richter, A., Weber, M., Noel, S., Wittrock, F. Bovensmann, H., Munro, R., Lang, R., and Burrows, J.P.: GOME-2 optical degradation as seen in level 2 data time series (2007 - 2010; $\mathrm{BrO}, \mathrm{NO} 2, \mathrm{HCHO}, \mathrm{H} 2 \mathrm{O}$, and O3), EGU General Assembly, Vienna, Austria, April 2011, 2011.

Errera, Q. and Fonteyn, D.: Four-dimensional variational chemical assimilation of CRISTA stratospheric measurements, J. Geophys. Res., 106, 12 253-12 265, 2001.

Falk, S. and Sinnhuber, B.-M.: Polar boundary layer bromine explosion and ozone depletion events in the chemistryclimate model EMAC v2.52: implementation and evaluation of AirSnow algorithm, Geosci. Model Dev., 11, 1115-1131, https://doi.org/10.5194/gmd-11-1115-2018, 2018.

Fan, S. M. and Jacob, D. J.: Surface ozone depletion in the Arctic spring sustained by bromine reactions on aerosols, Nature, 359 , 522-524, 1992.

Fernandez, R. P., Carmona-Balea, A., Cuevas, C. A., Barrera, J. A., Kinnison, D. E., Lamarque, J.-F., Blaszczak-Boxe, C., Kim, K., Choi, W., Hay, T., Blechschmidt, A.-M., Schönhardt, A., Burrows, J. P., and Saiz-Lopez, A.: Modeling the Sources and Chemistry of Polar Tropospheric Halogens $(\mathrm{Cl}, \mathrm{Br}$, and I) Using the CAM-Chem Global Chemistry-Climate Model, J. Adv. Model. Earth Sy., 11, 2259-2289, doi:10.1029/2019MS001655, 2019.

Fickert, S., Adams, J.W., and Crowley, J. N.: Activation of Br2 and $\mathrm{BrCl}$ via uptake of $\mathrm{HOBr}$ onto aqueous salt solutions, J. Geophys. Res., 104, 23 719-23 727, doi:10.1029/1999JD900359, 1999.

Fleischmann, O. C., Hartmann, M., Burrows, J. P., and Orphal, J.: New ultraviolet absorption cross-sections of $\mathrm{BrO}$ at atmospheric temperatures measured by time-windowing Fourier transform spectroscopy, J. Photoch. Photobio. A, 168, 117-132, 2004.

Frey, M. M., Norris, S. J., Brooks, I. M., Anderson, P. S., Nishimura, K., Yang, X., Jones, A. E., Nerentorp Mastromonaco, M. G., Jones, D. H., and Wolff, E. W.: First direct observation of sea salt aerosol production from blowing snow above sea ice, Atmos. Chem. Phys., 20, 2549-2578, https://doi.org/10.5194/acp20-2549-2020, 2020.

Galley, R. J., Babb, D., Ogi, M., Else, B. G. T., Geilfus, N.-X., Crabeck, O., Barber, D. G., and Rysgaard, S.: Replacement of multiyear sea ice and changes in the open water season duration in the Beaufort Sea since 2004, J. Geophys. Res.-Oceans, 121, 1806-1823, doi:10.1002/2015JC011583, 2016.

García, O. E., Sepúlveda, E., Schneider, M., Hase, F., August, T., Blumenstock, T., Kühl, S., Munro, R., Gómez-Peláez, Á. J., Hultberg, T., Redondas, A., Barthlott, S., Wiegele, A., González, Y., and Sanromá, E.: Consistency and quality assessment of the Metop-A/IASI and Metop-B/IASI operational trace gas products $\left(\mathrm{O}_{3}, \mathrm{CO}, \mathrm{N}_{2} \mathrm{O}, \mathrm{CH}_{4}\right.$, and $\left.\mathrm{CO}_{2}\right)$ in the subtropical North Atlantic, Atmos. Meas. Tech., 9, 2315-2333, https://doi.org/10.5194/amt9-2315-2016, 2016

Georgoulias, A. K., van der A, R. J., Stammes, P., Boersma, K. F., and Eskes, H. J.: Trends and trend reversal detection in 2 decades of tropospheric $\mathrm{NO}_{2}$ satellite observations, Atmos. Chem. Phys., 19, 6269-6294, https://doi.org/10.5194/acp19-6269-2019, 2019.

Giordano, M. R., Kalnajs, L. E., Goetz, J. D., Avery, A. M., Katz, E., May, N. W., Leemon, A., Mattson, C., Pratt, K. A., and DeCarlo, P. F.: The importance of blowing snow to halogencontaining aerosol in coastal Antarctica: influence of source re- 
gion versus wind speed, Atmos. Chem. Phys., 18, 16689-16711, https://doi.org/10.5194/acp-18-16689-2018, 2018.

Halfacre, J. W., Shepson, P. B., and Pratt, K. A.: pH-dependent production of molecular chlorine, bromine, and iodine from frozen saline surfaces, Atmos. Chem. Phys., 19, 4917-4931, https://doi.org/10.5194/acp-19-4917-2019, 2019.

Hansen, J., Sato, M., and Ruedy, R.: Radiative forcing and climate response, J. Geophys. Res., 102, 6831-6864, doi:10.1029/96JD03436, 1997.

Hendrick, F., Johnston, P.V., De Mazière, M., Fayt, C., Hermans, C., Kreher, K., Theys, N., and Van Roozendael, M.: Onedecade trend analysis of stratospheric $\mathrm{BrO}$ over Harestua $\left(60^{\circ} \mathrm{N}\right)$ and Lauder $\left(45^{\circ} \mathrm{S}\right)$ reveals a decline, Geophys. Res. Lett., 35, L14801, doi:10.1029/2008GL034154, 2008.

Hollwedel, J., Wenig, M., Beirle, S., Kraus, S., Kühl, S., WilmsGrabe, W., Platt, U., and Wagner, T.: Year-to-Year Variations of Polar Tropospheric BrO as seen by GOME, Adv. Space Res., 34, 804-808, doi:10.1016/j.asr.2003.08.060, 2004.

Huang, J., Jaeglé, L., Chen, Q., Alexander, B., Sherwen, T., Evans, M. J., Theys, N., and Choi, S.: Evaluating the impact of blowingsnow sea salt aerosol on springtime $\mathrm{BrO}$ and $\mathrm{O}_{3}$ in the Arctic, Atmos. Chem. Phys., 20, 7335-7358, https://doi.org/10.5194/acp20-7335-2020, 2020.

Jacobi, H., Kaleschke, L., Richter, A., Rozanov, A., and Burrows, J. P.: Observation of a fast ozone loss in the marginal ice zone of the Arctic Ocean, J. Geophys. Res., 111, D15309, doi:10.1029/2005JD006715, 2006.

Jeffries, O. M., Overland, E. J., and Perovich K. D.: The Arctic shifts to a new normal, Phys. Today, 66, 35, doi:10.1063/PT.3.2147, 2013.

Jones, A. E., Anderson, P. S., Begoin, M., Brough, N., Hutterli, M. A., Marshall, G. J., Richter, A., Roscoe, H. K., and Wolff, E. W.: BrO, blizzards, and drivers of polar tropospheric ozone depletion events, Atmos. Chem. Phys., 9, 4639-4652, https://doi.org/10.5194/acp-9-4639-2009, 2009.

Kaleschke, L., Richter, A., Burrows, J. P., Afe, O., Heygster, G., Notholt, J., Rankin, A. M., Roscoe, H. K., Hollwedel, J., Wagner, T., and Jacobi, H.-W.: Frost flowers on sea ice as a source of sea salt and their influence on tropospheric halogen chemistry, Geophys. Res. Lett., 31, L16114, doi:10.1029/2004GL020655, 2004.

Kalnay, E., Kanamitsu, M., Kistler, R., Collins, W., Deaven, D., Gandin, L., Iredell, M., Saha, S., White, G., Woollen, J., Zhu, Y., Leetmaa, A., Reynolds, R., Chelliah, M., Ebisuzaki, W., Higgins, W., Janowiak, J., Mo, K. C., Ropelewski, C., Wang, J., Jenne, R., and Joseph, D.: The NCEP/NCAR 40-Year Reanalysis Project, B. Am. Meteorol. Soc., 77, 437-471, doi:10.1175/15200477(1996)077<0437:tnyrp>2.0.CO;2, 1996.

Kendall, M.G.: Rank Correlation Methods, 4th edn., Charles Friffin, London, 1975.

Kirtman, B., Power, S.B., Adedoyin, J.A., Boer, G.J., Bojariu, R., Camilloni, I., Doblas-Reyes, F.J., Fiore, A.M., Kimoto, M., Meehl, G.A., Prather, M., Sarr, A., Schär, C., Sutton, R., Van Oldenborgh, G.J., Vecchi, G., and Wang, H.J: Near-term Climate Change: Projections and Predictability, in: Climate Change 2013: The Physical Science Basis. Contribution of Working Group I to the Fifth Assessment Report of the Intergovernmental Panel on Climate Change, edited by: Stocker, T.F., Qin, D., Plattner, G.-K., Tignor, M., Allen, S.K., Boschung, J., Nauels, A., Xia, Y., Bex,
V., and Midgley, P.M., Cambridge University Press, Cambridge, United Kingdom, and New York, NY, USA, 2013.

Krijger, J. M., Snel, R., Aben, I., and Landgraf, J.: Absolute calibration and degradation of SCIAMACHY/GOME reflectances, in: Proceedings of the Envisat Symposium, Montreux, Switzerland, 23-27 April 2007 (ESA SP-636, July 2007), 2007.

Kroon, M., Haan, J. F. de, Veefkind, J. P., Froidevaux, L., Wang, R., Kivi, R., and Hakkarainen, J. J.: Validation of operational ozone profiles from the Ozone Monitoring Instrument, J. Geophys. Res.-Atmos., 116, doi:10.1029/2010JD015100, 2011.

Lelieveld, J., Gromov, S., Pozzer, A., and Taraborrelli, D.: Global tropospheric hydroxyl distribution, budget and reactivity, Atmos. Chem. Phys., 16, 12477-12493, https://doi.org/10.5194/acp-1612477-2016, 2016.

Lu, J. Y., Schroeder, W. H., Barrie, L. A., Steffen, A., Welch, H. E., Martin, K., Lockhart, L., Hunt, R. V., Boila, G., and Richter, A.: Magnification of atmospheric mercury deposition to Polar regions in springtime: The link to tropospheric ozone depletion chemistry, Geophys. Res. Lett., 28, 3219-3222, 2001.

Mann, H.B.: Nonparametric Tests against Trend, Econometrica, 13, 245-259, doi:10.2307/1907187, 1945.

McCusker, K. E., Fyfe, J. C., and Sigmond, M.: Twenty-five winters of unexpected Eurasian cooling unlikely due to Arctic sea-ice loss, Nat. Geosci., 9, 838-842, doi:10.1038/ngeo2820, 2016.

Mioduszewski, J., Vavrus, S., and Wang, M.: Diminishing Arctic Sea Ice Promotes Stronger Surface Winds, J. Climate, 31, 81018119, doi:10.1175/JCLI-D-18-0109.1, 2018.

Mouginot, J., Rignot, E., Bjørk, A. A., van den Broeke, M., Millan, R., Morlighem, M., Noël, B., Scheuchl, B., and Wood, M.: Forty-six years of Greenland Ice Sheet mass balance from 1972 to 2018, Proc. Natl. Acad. Sci. USA, 116, 9239, doi:10.1073/pnas.1904242116, 2019.

Munro, R., Lang, R., Klaes, D., Poli, G., Retscher, C., Lindstrot, R., Huckle, R., Lacan, A., Grzegorski, M., Holdak, A., Kokhanovsky, A., Livschitz, J., and Eisinger, M.: The GOME2 instrument on the Metop series of satellites: instrument design, calibration, and level 1 data processing - an overview, Atmos. Meas. Tech., 9, 1279-1301, https://doi.org/10.5194/amt-9-12792016, 2016.

Ogawa, F., Keenlyside, N., Gao, Y., Koenigk, T., Yang, S., Suo, L., Wang, T., Gastineau, G., Nakamura, T., Cheung, H. N., Omrani, N.-E., Ukita, J., and Semenov, V.: Evaluating Impacts of Recent Arctic Sea Ice Loss on the Northern Hemisphere Winter Climate Change, Geophys. Res. Lett., 45, 3255-3263, https://doi.org/10.1002/2017GL076502, 2018.

Peterson, P. K., Pöhler, D., Sihler, H., Zielcke, J., General, S., Frieß, U., Platt, U., Simpson, W. R., Nghiem, S. V., Shepson, P. B., Stirm, B. H., Dhaniyala, S., Wagner, T., Caulton, D. R., Fuentes, J. D., and Pratt, K. A.: Observations of bromine monoxide transport in the Arctic sustained on aerosol particles, Atmos. Chem. Phys., 17, 7567-7579, https://doi.org/10.5194/acp17-7567-2017, 2017.

Peterson, P. K., Pöhler, D., Zielcke, J., General, S., Frieß, U., Platt, U., Simpson, W. R., Nghiem, S. V., Shepson, P. B., Stirm, B. H., and Pratt, K. A.: Springtime Bromine Activation over Coastal and Inland Arctic Snowpacks, ACS Earth Space Chem., 2, 10751086, doi:10.1021/acsearthspacechem.8b00083, 2018.

Peterson, P. K., Simpson, W. R., and Nghiem, S. V.: Variability of bromine monoxide at Barrow, Alaska, over four 
halogen activation (March-May) seasons and at two onice locations, J. Geophys. Res.-Atmos., 121, 1381-1396, doi:10.1002/2015JD024094, 2016.

Pithan, F. and Mauritsen, T.: Arctic amplification dominated by temperature feedbacks in contemporary climate models, Nat. Geosci., 7, 181-184, doi:10.1038/ngeo2071, 2014.

Platt, U. and Lehrer, E.: Arctic Tropospheric Ozone Chemistry, ARCTOC, Final Report of the EU-Project No. EV5V-CT930318, Heidelberg, 1997.

Platt, U., and Perner, D.: Measurements of Atmospheric Trace Gases by Long Path Differential UV/Visible Absorption Spectroscopy, Optical and Laser Remote Sensing, Springer Series Opti., 39, 97-105 doi:10.1007/978-3-540-39552-2_13, 1983.

Platt, U., and Stutz, J.: Differential Optical Absorption Spectroscopy: Principles and Applications, Springer-Verlag, Berlin Heidelberg, 2008.

Pratt, K. A., Custard, K. D., Shepson, P. B., Douglas, T. A., Pöhler, D., General, S., Zielcke, J., Simpson, W. R., Platt, U., Tanner, D. J., and Huey, L. G.: Photochemical production of molecular bromine in Arctic surface snowpacks, Nat. Geosci., 6, 351, doi:10.1038/ngeo1779, 2013

Rankin, A. M., Wolff, E. W., and Martin, S.: Frost flowers - implications for tropospheric chemistry and ice core interpretation, J. Geophys. Res., 107, 4683, doi:10.1029/2002JD002492, 2002.

Richter, A., Wittrock, F., Eisinger, M., and Burrows, J. P.: GOME observations of tropospheric $\mathrm{BrO}$ in Northern Hemispheric spring and summer 1997, Geophys. Res. Lett., 25, 2683-2686, doi:10.1029/98GL52016, 1998.

Richter, A., Wittrock, F., Ladstatter-Weißenmayer, A., and Burrows, J. P.: GOME measurements of stratospheric and tropospheric BrO, Adv. Space Res., 29, 1667-1672, doi:10.1016/S02731177(02)00123-0, 2002.

Richter-Menge, J., Overland, E. J., Mathis, T. J., and Osborne, E.: Arctic Report Card, 925, available at: http://www.arctic.noaa. gov/Report-Card (last access: 1 February 2020), 2017.

Ridley, B. A., Zeng, T., Wang, Y., Atlas, E. L., Browell, E. V., Hess, P. G., Orlando, J. J., Chance, K., and Richter, A.: An ozone depletion event in the sub-arctic surface layer over Hudson Bay, Canada, J. Atmos. Chem., 57, 255-280, doi:10.1007/s10874007-9072-z, 2007.

Saiz-Lopez, A. and von Glasow, R.: Reactive halogen chemistry in the troposphere, Chem. Soc. Rev., 41, 6448-6472, doi:10.1039/C2CS35208G, 2012.

Salawitch, R.: Biogenic bromine, Nature, 439, 275-277, 2006.

Sander, R. and Crutzen, P. J.: Model study indicating halogen activation and ozone destruction in polluted air masses transported to the sea, J. Geophys. Res.-Atmos., 101, 9121-9138, doi:10.1029/95JD03793, 1996.

Sander, R., Burrows, J., and Kaleschke, L.: Carbonate precipitation in brine - a potential trigger for tropospheric ozone depletion events, Atmos. Chem. Phys., 6, 4653-4658, https://doi.org/10.5194/acp-6-4653-2006, 2006.

Schroeder, W. H., Anlauf, K. G., Barrie, L. A., Lu, J. Y., Steffen, A., and Schneeberger, D. R.: Arctic springtime depletion of mercury, Nature, 394, 331-332, 1998.

Seo, S., Richter, A., Blechschmidt, A.-M., Bougoudis, I., and Burrows, J. P.: First high-resolution BrO column retrievals from TROPOMI, Atmos. Meas. Tech., 12, 2913-2932, https://doi.org/10.5194/amt-12-2913-2019, 2019a.
Seo, S., Richter, A., Blechschmidt, A.-M., Bougoudis, I., and Burrows, J. P.: Spatial distribution of enhanced $\mathrm{BrO}$ and its relation to meteorological parameters in Arctic and Antarctic sea ice regions, Atmos. Chem. Phys. Discuss., https://doi.org/10.5194/acp-2019-996, in review, 2019 b.

Serdyuchenko, A., Gorshelev, V., Weber, M., Chehade, W., and Burrows, J. P.: High spectral resolution ozone absorption crosssections - Part 2: Temperature dependence, Atmos. Meas. Tech., 7, 625-636, https://doi.org/10.5194/amt-7-625-2014, 2014.

Serreze, C. M., Barry, G. R.: Processes and impacts of Arctic amplification: A research synthesis, Global Planet. Change, 77, 85-96, doi:10.1016/j.gloplacha.2011.03.004, 2011.

Serreze, M. C. and Meier, W. N.: The Arctic's sea ice cover: trends, variability, predictability, and comparisons to the Antarctic, Ann. Ny. Acad. Sci., 1436, 36-53, doi:10.1111/nyas.13856, 2019.

Sihler, H., Platt, U., Beirle, S., Marbach, T., Kühl, S., Dörner, S., Verschaeve, J., Frieß, U., Pöhler, D., Vogel, L., Sander, R., and Wagner, T.: Tropospheric BrO column densities in the Arctic derived from satellite: retrieval and comparison to ground-based measurements, Atmos. Meas. Tech., 5, 27792807, https://doi.org/10.5194/amt-5-2779-2012, 2012.

Simpson, W. R., Carlson, D., Hönninger, G., Douglas, T. A., Sturm, M., Perovich, D., and Platt, U.: First-year sea-ice contact predicts bromine monoxide $(\mathrm{BrO})$ levels at Barrow, Alaska better than potential frost flower contact, Atmos. Chem. Phys., 7, 621-627, https://doi.org/10.5194/acp-7-621-2007, 2007.

Snel, R.: In-orbit optical path degradation: GOME experience and SCIAMACHY prediction, ERS-ENVISAT Symp. SP-461, proceedings on CD file 316snel.pdf, 2000.

Stjern, C. W., Lund, M. T., Samset, B. H., Myhre, G., Forster, P. M., Andrews, T., Boucher, O., Faluvegi, G., Fläschner, D., Iversen, T., Kasoar, M., Kharin, V., Kirkevåg, A., Lamarque, J.-F., Olivié, D., Richardson, T., Sand, M., Shawki, D., Shindell, D., Smith, C. J., Takemura, T. and Voulgarakis, A.: Arctic Amplification Response to Individual Climate Drivers, J. Geophys. Res.-Atmos., 124, 6698-6717, doi:10.1029/2018JD029726, 2019.

Stone, D., Sherwen, T., Evans, M. J., Vaughan, S., Ingham, T., Whalley, L. K., Edwards, P. M., Read, K. A., Lee, J. D., Moller, S. J., Carpenter, L. J., Lewis, A. C., and Heard, D. E.: Impacts of bromine and iodine chemistry on tropospheric $\mathrm{OH}$ and $\mathrm{HO}_{2}$ : comparing observations with box and global model perspectives, Atmos. Chem. Phys., 18, 3541-3561, https://doi.org/10.5194/acp-18-3541-2018, 2018.

Stroeve, J. C., Kattsov, V., Barrett, A., Serreze, C. M., Pavlova, T., Holland, M., and Meier, W. N.: Trends in Arctic sea ice extent from CMIP5, CMIP3 and observations, Geophys. Res. Lett., 39, L16502, doi:10.1029/2012GL052676, 2012.

Theys, N., Van Roozendael, M., Errera, Q., Hendrick, F., Daerden, F., Chabrillat, S., Dorf, M., Pfeilsticker, K., Rozanov, A., Lotz, W., Burrows, J. P., Lambert, J.-C., Goutail, F., Roscoe, H. K., and De Mazière, M.: A global stratospheric bromine monoxide climatology based on the BASCOE chemical transport model, Atmos. Chem. Phys., 9, 831-848, https://doi.org/10.5194/acp-9831-2009, 2009.

Theys, N., Van Roozendael, M., Hendrick, F., Yang, X., De Smedt, I., Richter, A., Begoin, M., Errera, Q., Johnston, P. V., Kreher, K., and De Mazière, M.: Global observations of tropospheric BrO columns using GOME-2 satellite data, Atmos. Chem. Phys., 11, 1791-1811, https://doi.org/10.5194/acp-11-1791-2011, 2011. 
Toohey, D. W., Anderson, J. G., Brune, W. H. and Chan, K. R.: In situ measurements of $\mathrm{BrO}$ in the Arctic stratosphere, Geophys. Res. Lett., 17, 513-516, doi:10.1029/GL017i004p00513, 1990.

Toyota, K., McConnell, J. C., Lupu, A., Neary, L., McLinden, C. A., Richter, A., Kwok, R., Semeniuk, K., Kaminski, J. W., Gong, S.-L., Jarosz, J., Chipperfield, M. P., and Sioris, C. E.: Analysis of reactive bromine production and ozone depletion in the Arctic boundary layer using 3-D simulations with GEM-AQ: inference from synoptic-scale patterns, Atmos. Chem. Phys., 11, 3949-3979, https://doi.org/10.5194/acp-11-3949-2011, 2011.

Tschudi, M., Meier, W. N., Stewart, J. S., Fowler, C., and Maslanik., J. EASE-Grid Sea Ice Age, Version 4, NASA National Snow and Ice Data Center Distributed Active Archive Center, Boulder, Colorado, USA, doi:10.5067/UTAV7490FEPB, 2019.

Tuckermann, M., Ackermann, R., Golz, C., Lorenzen-Schmidt, H., Senne, T., Stutz, J., Trost, B., Unold, W., and Platt, U.: DOAS-observation of halogen radical-catalysed arctic boundary layer ozone destruction during the ARCTOC-campaigns 1995 and 1996 in Ny-Alesund, Spitsbergen, Tellus B, 49, 533-555, doi:10.1034/j.1600-0889.49.issue5.9.x, 1997.

Van Roozendael, M., De Smedt, I., Fayt, C., Hendrick, F., Oetjen, H., Wittrock, F., Richter, A., and Afe, O.: First validation of SCIAMACHY BrO columns, in: Proceedings of the Second Workshop on the Atmospheric Chemistry Validation of ENVISAT (ACVE-2), Frascati, Italy, 3-7 May 2004, ESC02MVR, 2004.

Vountas, M., Rozanov, V. V., and Burrows, J. P.: Ring effect: Impact of rotational Raman scattering on radiative transfer in earth's atmosphere, J. Quant. Spectrosc. Ra., 60, 943-961, doi:10.1016/s0022-4073(97)00186-6, 1998.

Wagner, T. and Platt, U.: Satellite mapping of enhanced BrO concentrations in the troposphere, Nature, 395, 486-490, 1998.

Wagner, T., Leue, C., Wenig, M., Pfeilsticker, K., and Platt, U.: Spatial and temporal distribution of enhanced boundary layer $\mathrm{BrO}$ concentrations measured by the GOME instrument aboard ERS2, J. Geophys. Res, 106, 24225-24235, 2001.
Weatherhead, E. C., Reinsel, G. C., Tiao, G. C., Meng, X.-L., Choi, D., Cheang, W.-K., Keller, T., DeLuisi, J., Wuebbles, D. J., Kerr, J. B., Miller, A. J., Oltmans, S. J. and Frederick, J. E.: Factors affecting the detection of trends: Statistical considerations and applications to environmental data, J. Geophys. Res.-Atmos., 103, 17 149-17 161, doi:10.1029/98JD00995, 1998.

Weber, M., Chehade, W., Fioletov, V. E., Frith, S. M., Long, C. S., Steinbrecht, W., and Wild, J. D.: [Global Climate] Stratospheric ozone [in "State of the Climate in 2012"], Bull. Amer. Meteor. Soc., 94, S36-S37, 2013.

Yang, W. and Magnusdottir, G.: Year-to-year Variability in Arctic Minimum Sea Ice Extent and its Preconditions in Observations and the CESM Large Ensemble Simulations, Sci. Rep., 8, 9070, doi:10.1038/s41598-018-27149-y, 2018.

Yang, X., Blechschmidt, A.-M., Bognar, K., McClure-Begley, A., Morris, S., Petropavlovskikh, I., Richter, A., Skov, H., Strong, K., Tarasick, D., Uttal, T., Vestenius, M., and Zhao, X.: Pan-Arctic surface ozone: modelling vs measurements, Atmos. Chem. Phys. Discuss., https://doi.org/10.5194/acp-2019-984, in review, 2020.

Yang, X., Pyle, J. A., and Cox, R. A.: Sea salt aerosol production and bromine release: Role of snow on sea ice, Geophys. Res. Lett., 35, L16815, doi:10.1029/2008GL034536, 2008.

Yang, X., Pyle, J. A., Cox, R. A., Theys, N., and Van Roozendael, M.: Snow-sourced bromine and its implications for polar tropospheric ozone, Atmos. Chem. Phys., 10, 7763-7773, https://doi.org/10.5194/acp-10-7763-2010, 2010.

Zhao, X., Strong, K., Adams, C., Schofield, R., Yang, X., Richter, A., Friess, U., Blechschmidt, A. M., and Koo, J. H.: A case study of a transported bromine explosion event in the Canadian high arctic, J. Geophys. Res. Atmos., 121, 457-477, doi:10.1002/2015JD023711, 2016. 